PNL-2779

UC-78

\title{
Description of Alternative Steady-State Fuel Cycles
}
A. J. Boegel
E. T. Merrill
D. F. Newman
A. M. Nolan

November 1978

Prepared for the U.S. Department of Energy under Contract EY-76-C-06-1830

Pacific Northwest Laboratory

Operated for the U.S. Department of Energy

by Battelle Memorial Institute 


\title{
NOTICE
}

This report was prepared as an account of work sponsored by the United States Government. Neither the United States nor the Department of Energy, nor any of their employees, nor any of their contractors, subcontractors, or their employees, makes any warranty, express or implied, or assumes any legal liability or responsibility for the accuracy, completeness or usefulness of any information, apparatus, product or process disclosed, or represents that its use would not infringe privately owned rights.

The views, opinions and conclusions contained in this report are those of the contractor and do not necessarily represent those of the United States Government or the United States Department of Energy.

\author{
PACIFIC NORTHWEST LABORATORY \\ operated by \\ BATTELLE \\ for the \\ UNITED STATES DEPARTMENT OF ENERGY
}

Under Contract EY-76-C-06-1830

Printed in the United States of America Available from

National Technical Information Service United States Department of Commerce

5285 Port Royal Road

Springfield, Virginia 22151

Price: Printed Copy $\mathbf{s}$

$\because$ Microfiche $\$ 3.00$

NTIS

•Pages Selling Price

$\begin{array}{ll}001-025 & \$ 4.00 \\ 026-050 & \$ 4.50 \\ 051-075 & \$ 5.25 \\ 076-100 & \$ 6.00 \\ 101-125 & \$ 6.50 \\ 126-150 & \$ 7.25 \\ 151-175 & \$ 8.00 \\ 176-200 & \$ 9.00 \\ 201-225 & \$ 9.25 \\ 226-250 & \$ 9.50 \\ 251-275 & \$ 10.75 \\ 276-300 & \$ 11.00\end{array}$


PNL-2779

UC-78

\section{2}

\section{DESCRIPTION OF ALTERNATIVE}

STEADY-STATE FUEL CYCLES
A. J. Boegel
E. T. Merrill
D. F. Newman
A. M. Nolan

November 1978

Prepared for the U.S. Department of Energy

under Contract EY-76-C-06-1830

Pacific Northwest Laboratory

Richland, Washington 99352 


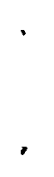




\section{CONTENTS}

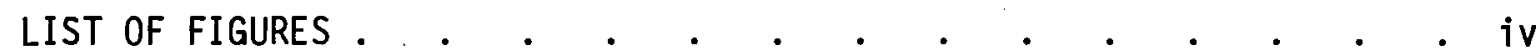

LIST OF TABLES • • • • • • • • • • • • • • . v v

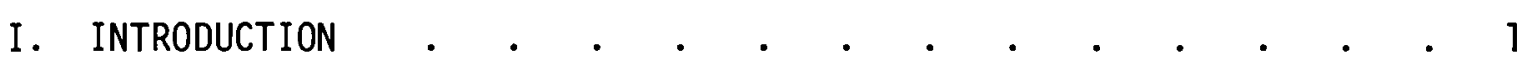

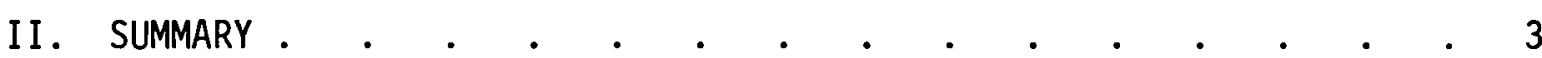

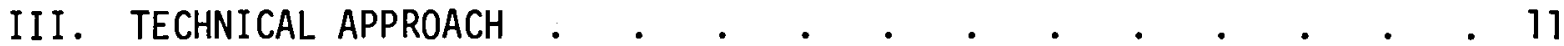

IV. IDENTIFICATION OF ALTERNATIVE CLOSED FUEL CYCLES • • • • • 15

V. ISOTOPIC MASS FLOW RATES FOR ALTERNATIVE CLOSED

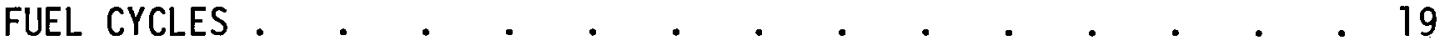

VI. RESOURCE AND ENRICHMENT DEMAND COMPARISONS • $\quad \cdot \quad \cdot \quad \cdot \quad \cdot \quad \cdot \quad \cdot 37$

VII. RADIATION LEVELS FROM SELECTED FUELS . • • • • • • • • . 41

REPROCESSED FUEL . . . . . . . . . . . . . . 41

PRE-IRRADIATED FUEL . . . . . . . . . . . . . . 45

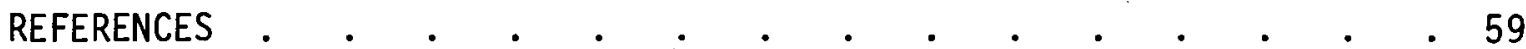

APPENDICES

A. Description of the Nuclear Fuel Cycle . . . . . . . . A.1

B. Normalization of Nuclear Fuel Burnup Model . . . . . . B.l

C. Detailed Description of Alternative Fuel Cycle

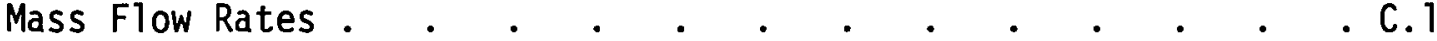




\section{LIST OF FIGURES}

1-7 Simplified Representation of the Flow of Fissile Material Within Each Closed System . . . . . . 4-5

8-14 Alternative Fuel Cycle Descriptions with Averaged Compositions. . . . . . . . . . . 23-35

15-24 Dose Rates from Selected Fuel Types at One Meter as a Result of Different Reprocessing and Pre-Irradiation Schemes . . . . . . . . . 49-58

C1-C7 Detailed Description of Alternative Fuel Cycle Mass Flow Rates 


\section{LIST OF TABLES}

1 Percent of Power Generation by Fuel Type at Equilibrium . . . 6

2 Range of Steady-State Feed Compositions for Refabrication . . 7

3 List of Alternative Closed Fuel Cycle Constituents . . . . 16

4 Fractional Power Generation by Fuel Type . . . . . . . 38

5 Resource and SWU Requirements . . . . . . . . . 39

6 Initial Fuel Compositions . . . . . . . . . . 42

7 Discharge Fuel Compositions . . . . . . . . . . 42

8 Sphere Compositions . . . . . . . . . . . . 44

9 Times Prior to Which a $100 \mathrm{R} / \mathrm{hr}$ per $\mathrm{kg}$ Fissile Material Diversion Deterrence Criterion Is Met for Selected Fuels and Various Reprocessing and Pre-Irradiation Schemes. . . . 47

B-1 Specific Fuel Type Modifications for ALTHAEA . . . . . B.3-B.5

C-1 Neutron Multiplication Constants at Two-Thirds Goal Exposure . . . . . . . . . . . . . c.2 


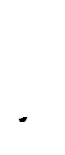




\section{INTRODUCTION}

Since the start of the U.S. commercial nuclear industry 20 years ago the dominant fuel cycle has been low enriched uranium (LEU) fuel in light water reactors (LWRS). Currently nearly $10 \%$ of the total U.S. electric power capability is generated by LWRs. During the last decade it was recognized that future costs of LEU fuel would increase as the deposits of high-grade uranium ore were exhausted and the price of enrichment would increase to reflect higher electrical costs. As a result, the commercial nuclear industry began developing improved reactor and fuel designs and demonstrating pilot-scale commercial fuel reprocessing and fuel refabrication. Plans were made and development was initiated to reprocess the spent LEU fuel to recover both the plutonium and the slightly enriched uranium remaining in the fuel. The Nuclear Fuel Services (NFS) reprocessing plant in West Valley, New York demonstrated that plutonium, uranium, and fission products in LWR spent fuel could be separated into separate streams. The separated plutonium was blended with uranium and refabricated into $\mathrm{UO}_{2}-\mathrm{PuO}_{2}$ pellet fuel using partially-shielded glove box operations. Demonstration irradiations were performed using this $\mathrm{UO}_{2}-\mathrm{PuO}_{2}$ fuel in both the Quad Cities boiling water reactor (BWR) and the San Onofre pressurized water reactor (PWR). These irradiations demonstrated that $\mathrm{UO}_{2}-\mathrm{PuO}_{2}$ fuel performance was within the design envelope for LEU fuel, which further encouraged the utilities and the fuel vendors to pursue plutonium recycle in LWRs. Both the General Electric Company and the Allied General Nuclear Services Company (AGNS) designed and constructed commerical scale spent fuel reprocessing plants. At the same time, the Westinghouse company designed a commercial-scale semi-remote $\mathrm{UO}_{2}-\mathrm{PuO}_{2}$ pellet fuel refabrication plant. A common design assumption was that plutonium would be completely separated from both uranium and fission products for recycle.

By the end of 1976, however, the Federal Government made major policy changes in regard to LWR spent fuel reprocessing and plutonium recycle. The essence of the current U.S. policy is to control the proliferation of nuclear 
weapons by limiting the spread of technologies and facilities which allow access to materials that could be used in weapons. As a result, spent fuel reprocessing was deferred indefinitely in the U.S., the Generic Environmental Statement on Mixed-0xide Fuels (GESMO) was terminated, and license applications by AGNS for the Barnwell Reprocessing Plant and by Westinghouse for the Anderson Fuel Refabrication Plant were not processed by NRC. The Administration initiated the Nonproliferation Alternatives Systems Assessment Program (NASAP) and the International Fuel Cycle Evaluation (INFCE) studies to convince the international community to develop a similar nuclear fuel cycle policy. In addition the Federal Government has offered to accept spent fuel from utilities for a one-time charge for interim storage and disposal.

The Nuclear Power Division of DOE has established technology development programs at PNL, SRL and ANL to investigate candidate alternative fuel cycles from the process and operations perspective. These programs are the Fuel Refabrication and Development Program (FRAD) at PNL, the Alternate Fuel Aqueous Processing Technology Programs (AFCT/TFCT) at SRL, and the Alternate Fuel NonAqueous Processing Technology Program at ANL. The purpose of these programs is to develop technical information to a point where the choice of a weapons proliferation resistant nuclear fuel cycle is not 1 imited by technology development.

All of these recent policy changes make it likely that significant changes will be made in the fuel cycle used by the U.S. nuclear industry in following years. Sixty different fuel cycles are currently being studied in the NASAP and INFCE studies. Some of the changes in the fuel cycles addressed in these studies are relatively minor, such as using a co-precipitated mixed-oxide (COMOX) fuel instead of a completely separated stream of plutonium. Other assumed changes in the fuel cycle are relatively major ones such as the use of thorium-based fuels or highly radioactive fuels requiring fuel cycle plants operated and maintained in a completely remote mode. The aforementioned studies are attempting to identify attractive fuel cycle systems (by October 1979) which have low proliferation risk, efficiently use resources, are economically competitive with LEU fuel, and are usable in current generation LWRs. 


\section{SUMMARY}

This study provides a first cut analys is for the FRAD program of a range of reference, steady-state, fresh and spent fuel compositions for the development of alternative fuels refabrication technology. Included are the resource requirements and separative work requirements and the material flows for each fuel cycle evaluated. However, since steady-state represents only a portion of the complete fuel cycle, a more in depth evaluation of each alternative fuel cycle will follow this analysis.

Each of the fuel types investigated in this report is composed of either plutonium-uranium ( $\mathrm{Pu}-\mathrm{U})$, denatured uranium-thorium (DU-Th), plutonium-thorium (Pu-Th), highly enriched uranium-thorium (HEU-Th) or low enriched uranium (LEU). Seven "closed cycles" were formed by coupling two or more of the above fuel types. The closed cycle concept assumes that all fissile material recovered from spent fuel is either recycled into fresh fuel, or retired to waste when its net reactivity worth is equal to or less than tails equivalence. A simplified representation of the flow of fissile material within each closed system can be seen in Figures 1-7. Additional fissile material required as makeup is introduced to the system from the enrichment cascade only. Each closed system presented in this study simulates the production of 1000 MWe in steady-state operation. The fraction of power generated by fuel type in each cycle can be seen in Table 1. The range of steady-state fuel compositions which must be refabricated can be seen in Table 2 .

The findings of this preliminary study indicated that, at equilibrium, those closed cycles which employ DU-Th or HEU-Th (Cycles 5-7) as the primary fuel are more efficient with respect to resource consumption than those cycles where LEU (Cycle 1-4) is used as the primary fuel. The primary fuels of cycles 1-4 yield plutonium which is used to drive the secondary (and tertiary) fuel types, while the primary fuel of cycles 5-7 produce U-233 as the principal fissile feed for the successive fuel types. Referring to Table 1, those cycles (1-4) which employ $\mathrm{Pu}$ recycle in the secondary fuel have a larger fraction of power generation in the primary fuel than those cycles (5-7) where 
FIGURE L: CYCLE I

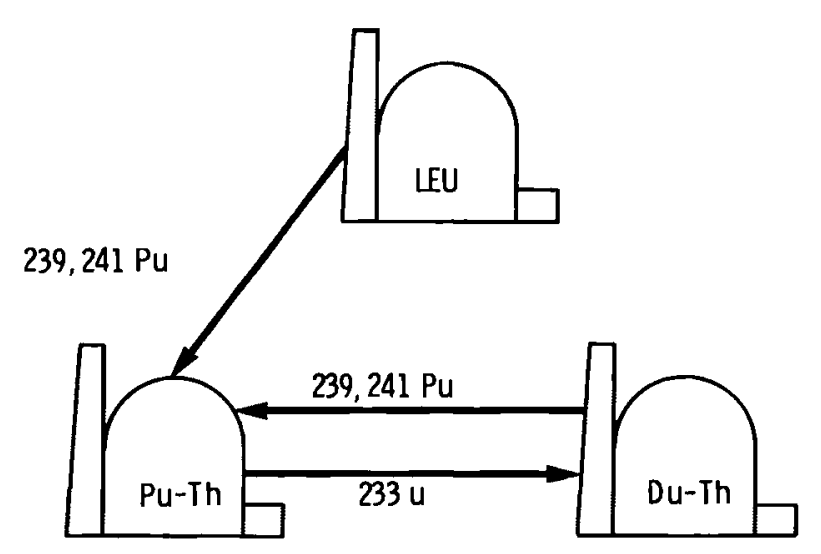

$$
\text { FIGURE 3: CYCLE } 3
$$

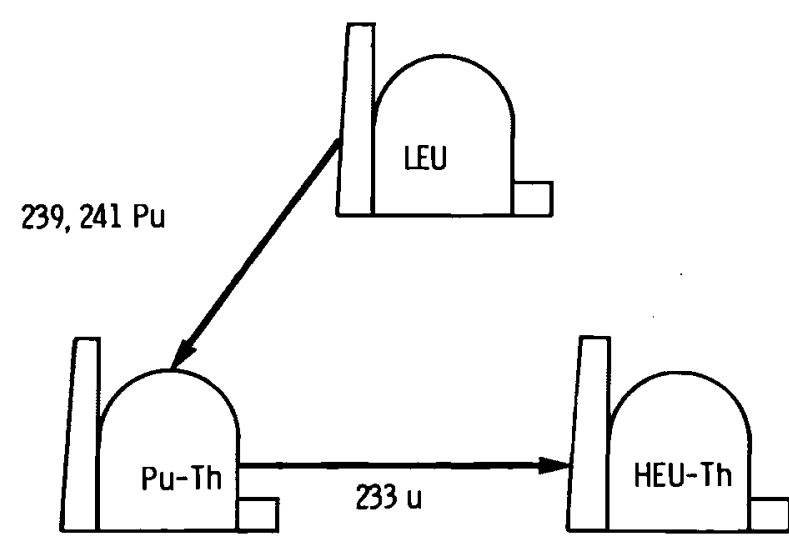

FIGURE 2: CYCLE 2

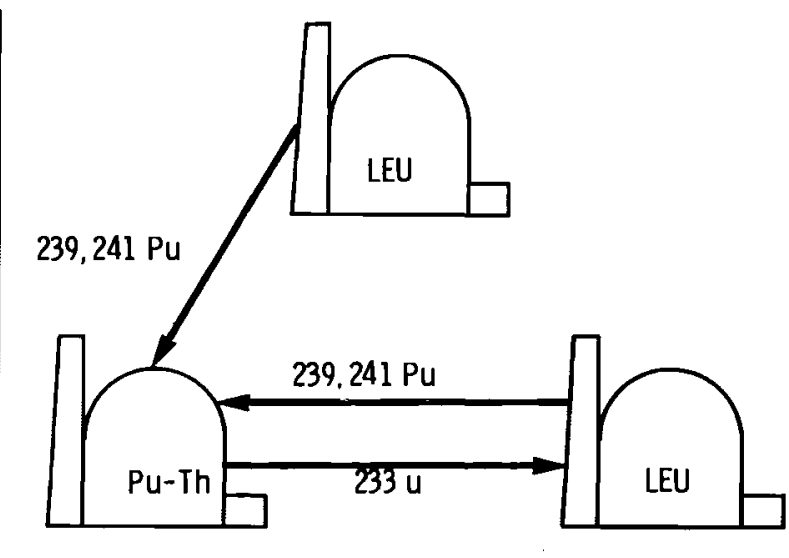

FIGURE 4: CYCLE 4

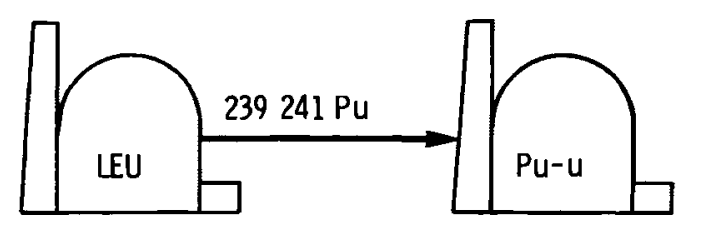

FIGURES 1-4. Simplified Representation of the Flow of Fissile Material Within Each Closed System 
FIGURE 5: CYCLE 5

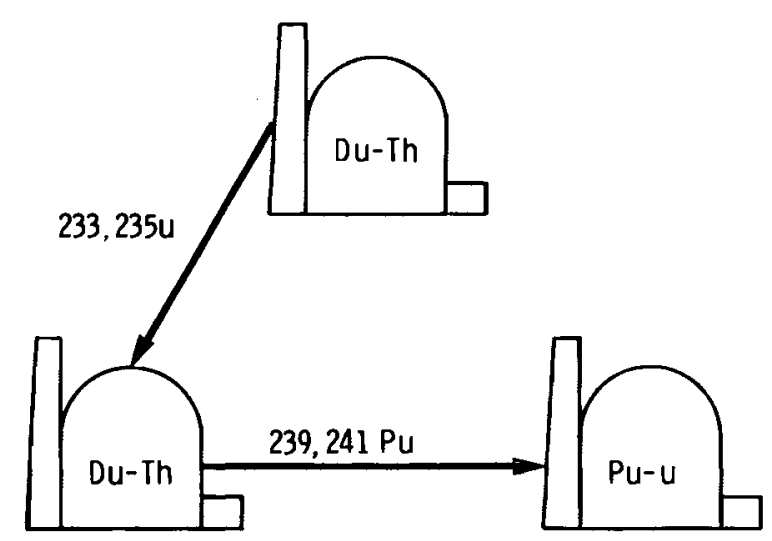

\section{FIGURE 6: CYCLE 6}

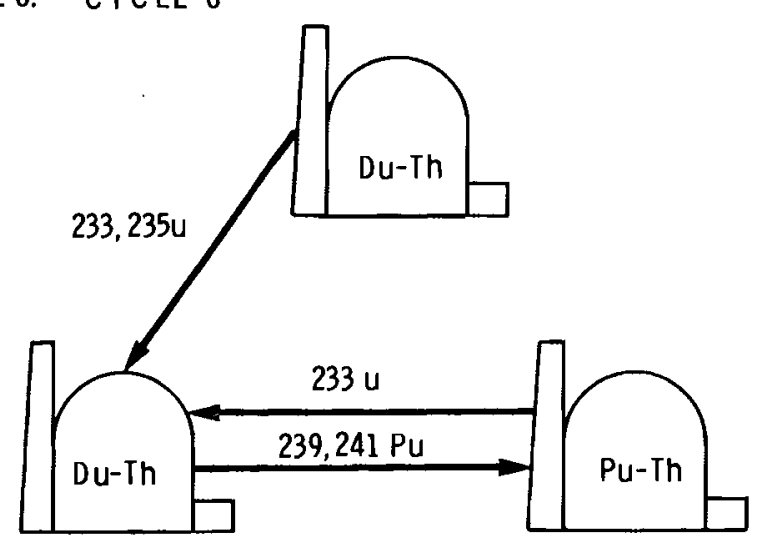

FIGURE 7: CYCLE 7

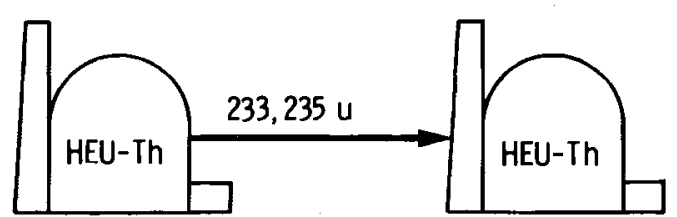

FIGURES 5-7. Simplified Representation of the Flow of Fissile Material Within Each Closed System 
TABLE 1. Percent of Power Generation by Fuel Type at Equilibrium

\begin{tabular}{|c|c|c|c|}
\hline Cycle No. & Primary & Secondary & Tertiary \\
\hline \multicolumn{4}{|l|}{ Cycle 1} \\
\hline $\begin{array}{l}\text { Fue1 Type } \\
\text { Power Fraction (\%) }\end{array}$ & $\begin{array}{l}\text { LEU } \\
74.6\end{array}$ & $\begin{array}{l}\text { Pu-Th } \\
13.1\end{array}$ & $\begin{array}{l}\text { Du-Th } \\
12.3\end{array}$ \\
\hline \multicolumn{4}{|l|}{ Cycle 2} \\
\hline $\begin{array}{l}\text { Fuel Type } \\
\text { Power Fraction (\%) }\end{array}$ & $\begin{array}{l}\text { LEU } \\
77.7\end{array}$ & $\begin{array}{l}\text { Pu-Th } \\
14.3\end{array}$ & $\begin{array}{l}\text { LEU } \\
8.1\end{array}$ \\
\hline \multicolumn{4}{|l|}{ Cycle 3} \\
\hline $\begin{array}{l}\text { Fue1 Type } \\
\text { Power Fraction (\%) }\end{array}$ & $\begin{array}{l}\text { LEU } \\
73.9\end{array}$ & $\begin{array}{l}\text { Pu-Th } \\
12.4\end{array}$ & $\begin{array}{l}\text { HEU-Th } \\
13.7\end{array}$ \\
\hline \multicolumn{4}{|l|}{ Cycle 4} \\
\hline $\begin{array}{l}\text { Fuel Type } \\
\text { Power Fraction (\%) }\end{array}$ & $\begin{array}{l}\text { LEU } \\
71.5\end{array}$ & $\begin{array}{l}\text { Pu-U } \\
28.5\end{array}$ & -- \\
\hline \multicolumn{4}{|l|}{ Cycle 5} \\
\hline $\begin{array}{l}\text { Fuel Type } \\
\text { Power Fraction (\%) }\end{array}$ & $\begin{array}{l}\text { DU-Th } \\
36.8\end{array}$ & $\begin{array}{l}\text { DU-Th } \\
46.1\end{array}$ & $\begin{array}{l}\text { Pu-U } \\
17.1\end{array}$ \\
\hline \multicolumn{4}{|l|}{ Cycle 6} \\
\hline $\begin{array}{l}\text { Fuel Type } \\
\text { Power Fraction (\%) }\end{array}$ & $\begin{array}{l}\text { DU-Th } \\
36.0\end{array}$ & $\begin{array}{l}\text { DU-Th } \\
56.6\end{array}$ & $\begin{array}{c}\text { Pu-Th } \\
7.4\end{array}$ \\
\hline \multicolumn{4}{|l|}{ Cycle 7} \\
\hline $\begin{array}{l}\text { Fuel Type } \\
\text { Power Fraction (\%) }\end{array}$ & $\begin{array}{l}\text { HEU-Th } \\
36.8\end{array}$ & $\begin{array}{l}\text { HEU-Th } \\
63.2\end{array}$ & $\begin{array}{l}-- \\
--\end{array}$ \\
\hline
\end{tabular}




\section{TABLE 2. Range of Steady-State Feed Compositions for Refabrication}

\begin{tabular}{|c|c|c|c|c|c|c|c|c|c|c|}
\hline & & & & ange of $R$ & fabricat & d Fuel Co & ositions & & & \\
\hline & Plut & ium Fuels & Ran & $\begin{array}{r}\text { of Pluto } \\
\text { ntent ( }\end{array}$ & & $\begin{array}{c}\text { Range } \\
\text { Content } i\end{array}$ & $\begin{array}{l}\text { Fissile } \\
\text { Plutoniu }\end{array}$ & (o) & & \\
\hline & & $2^{-P u 0_{2}}$ & & .5 to 25 & & & & & & \\
\hline & & $-\mathrm{PuO}_{2}$ & & .2 to 16 & & 73 & 052 & & & \\
\hline & & um Fuels & & $\begin{array}{l}\text { e of Uran } \\
\text { ntent }(\end{array}$ & & $\begin{array}{r}\text { Range } \\
\text { Content }\end{array}$ & $\begin{array}{l}\text { Fissile } \\
\text { Uranium }\end{array}$ & & & \\
\hline & $\mathrm{ThO}_{2}-\mathrm{UC}$ & $11 \% 233(\mathrm{U})$ & & 7 to 75 & & 14 & 04.7 & & & \\
\hline & $\mathrm{ThO}_{2}-\mathrm{UC}$ & $\left.12 \%{ }^{233} U\right)$ & & .3 to 20 & & 93 & 030 & & & \\
\hline & & & & ge of Ele & ental Co & nositions & y Fuel_T & & & \\
\hline & & & Uranium & & & & & Plutoniu & & \\
\hline Fuel Type & 233 & 234 & 235 & 236 & 238 & 238 & 239 & 240 & 241 & 242 \\
\hline$P u-T h$ & & & & & & $\begin{array}{l}0.2 \\
\text { to } \\
0.095\end{array}$ & $\begin{array}{c}0.5795 \\
\text { to } \\
0.2595\end{array}$ & $\begin{array}{c}0.2205 \\
\text { to } \\
0.3173\end{array}$ & $\begin{array}{l}0.1361 \\
\text { to } \\
0.2088\end{array}$ & $\begin{array}{l}0.0434 \\
\text { to } \\
0.1194\end{array}$ \\
\hline Du-Th & $\begin{array}{l}0.0510 \\
\text { to. } \\
0.033\end{array}$ & $\begin{array}{c}0.0054 \\
\text { to } \\
0.0134\end{array}$ & $\begin{array}{c}0.0750 \\
\text { to } \\
0.0130\end{array}$ & $\begin{array}{l}0.0252 \\
\text { to } \\
0.0340\end{array}$ & $\begin{array}{l}0.8433 \\
\text { to } \\
0.9067\end{array}$ & & & & & \\
\hline HEU-Th & $\begin{array}{l}0.7500 \\
\text { to } \\
0.1725\end{array}$ & $\begin{array}{c}0.2010 \\
\text { to } \\
0.5184\end{array}$ & $\begin{array}{c}0.042 \\
\text { to } \\
0.125\end{array}$ & $\begin{array}{l}0.0081 \\
\text { to } \\
0.1834\end{array}$ & & & & & & \\
\hline$P u-U$ & & & & & & $\begin{array}{c}0.0143 \\
\text { to } \\
0.0734\end{array}$ & $\begin{array}{c}0.5754 \\
\text { to } \\
0.6237\end{array}$ & $\begin{array}{c}0.2265 \\
\text { to } \\
0.1624\end{array}$ & $\begin{array}{c}0.1380 \\
\text { to } \\
0.1177\end{array}$ & $\begin{array}{l}0.0458 \\
\text { to } \\
0.0227\end{array}$ \\
\hline $\begin{array}{l}\text { U Recyle from } \\
\text { Pu-Th }\end{array}$ & 0.923 & 0.066 & 0.102 & 0.00091 & & & & & & \\
\hline
\end{tabular}


${ }^{233} U$ is recycled into the secondary fuel types. The effect of this is a higher $\mathrm{U}_{3} \mathrm{O}_{8}$ demand in cycles 1-4. Therefore, in the equilibrium condition the recycle of $233 \mathrm{U}$ in therium in LWRs appears more efficient from the standpoint of natural resource demand than the recycle of plutonium in either uranium or thorium.

Fuel Cycle 6 (DU-Th, DU-Th, Pu-Th) may be the most promising cycle for long term energy production since it has the lowest fraction of power generated by a fuel type (PU-Th) which would have to be contained within a secured center due to its potential use in a weapon. However, Cycle 6 may also offer advantages for control of weapons proliferation. This is due to the possibility of having concentration $(>5 \%)$ of ${ }^{238} \mathrm{Pu}$ present in the plutonium produced by the three fuel types which are associated with this cycle. It has been reported that concentrations of $5 \%$ or greater of ${ }^{238} \mathrm{Pu}$ thermally denatures any fuel type composed of plutonium and a fertile material. (1) This effect would make the fabrication and eventual use of plutonium in a weapon technically very difficult.

Cycle 7 has a slightly smaller resource demand, but due to the $93 \%$ enriched ${ }^{235} U$, this fuel must be produced, fabricated and used in a secured center. This requirement would impose large constraints on the deployment of that fue 1 cycle.

An investigation of the magnitudes of dose rates from reprocessed fue 1 and pre-irradiated fuel was performed for the following fuel types (LEU, $\mathrm{PuO}_{2}-\mathrm{UO}_{2}$ and ${ }^{233} \mathrm{UO}_{2}-\mathrm{ThO}_{2}$ ). The analys is determined under what conditions a diversion deterrence criterion of $100 \mathrm{R} / \mathrm{hr}$ per $\mathrm{kg}$ fissile material at a distance of one meter might be met by these fuels assuming various reprocessing and preirradiation schemes. Reprocessing of spent fuels was assumed to occur 300 days after discharge from a reactor. Fuel refabrication was assumed to take another 90 days. Thus, the dose rates must exceed $100 \mathrm{R} / \mathrm{hr}$ per $\mathrm{kg}$ at one meter for more than 390 days after discharge in order to meet the diversion deterrence criterion under these assumptions. 
Three reprocessing schemes were assumed for this analys is 1) complete separation of fission products and actinides, 2) separation of fission products only, and 3 ) Civex-like process with selected fission products remaining with the fuel material. Of the above three schemes, only the Civex-like process enabled the LEU and $\mathrm{PuO}_{2}-\mathrm{UO}_{2}$ fuels to meet the criterion for 110 days and 310 days, respectively, after refabrication. The $\mathrm{UO}_{2}-\mathrm{ThO}_{2}$ fuel will meet the criterion with this reprocessing scheme provided it is reprocessed and refabricated sooner, since this fuel falls below the $100 \mathrm{R} / \mathrm{hr}$ limit at 350 days after discharge from the reactor.

The two preirradiation schemes considered were 1) $0.1 \%$ burnup and 2) $1 \%$ burnup. Both of these schemes have the potential for satisfying the divergence deterrence dose rates required during shipping and handling fuel following refabrication. The $0.1 \%$ burnup preirradiation will meet the criterion for 80 days while a $1 \%$ burnup will meet the criterion for 300 days. These results were nearly the same for all three fuel types. The preirradiation scheme chosen would depend on the time needed to ship the preirradiated fuel to the reactor site and on dose rate limitations on fuel handling and shipping. 


\section{TECHNICAL APPROACH}

The "closed cycle" concept adopted for these studies is based on the assumption that all fissile materials recovered from spent fuel are either recycled into fresh fuel, or retired to waste after their net reactivity worths have been reduced to uranium "tails" equivalence. The only fissile material entering the cycle is ${ }^{235} \mathrm{U}$ obtained from natural uranium. This natural uranium is enriched to a given assay (i.e., LEU, denatured U, or HEU) for each closed cycle. No stock-piling of bred fissile material or spent fuel is permitted. All beneficial recycle of fissile materials recovered from spent fuel is exercised. Nonbeneficial recycle of uranium containing ${ }^{236} U$ and ${ }^{234} U$ isotopes in sufficient concentrations to reduce the net reactivity of the material to that of uranium "tails" is not exercised; this material is retired to waste. It was assumed that uranium which contains ${ }^{233} U$ cannot be enriched in a diffusion or centrifuge cascade because of the high gamma activity due to the presence of ${ }^{232} \mathrm{U}$.

The following conditions were assumed applicable to all fuel cycles:

- Al1 fuel is discharged from the reactor at goal exposure.

- Spent fuel discharge occurs annually.

- The total out-of-reactor cycle time is two years.

- Spent fue1 loss during reprocessing and refabrication is $1 \%$.

- Enrichment cascades remove uranium tails at $0.2 \%{ }^{235} \mathrm{U}$ assay.

A number of additional conditions were applied to simplify the fuel cycle analysis:

- The closed cycle was analyzed for LWRs in the steady-state mode.

- The LWR capacity was neither growing nor declining.

- The PWR was used as the reference model for LWRs.

- Mass flows were normalized to that for 1000 MWe capacity. 
Fuel burnup calculations were performed using the ALTHAEA computer code. (2) The resonance shielding treatment in ALTHAEA was calibrated to match discharge isotopic compositions computed by Combustion Engineering for each of seven basic fuel types, ${ }^{(3)}$ when the same initial compositions were used. These fuel types are: (1) $\left(3.2 \%{ }^{235} \mathrm{U}\right) \mathrm{UO}_{2}$, (2) $\mathrm{UO}_{2}-\mathrm{PuO}_{2}$, (3) $\mathrm{ThO}_{2}-\left(93 \%{ }_{235} \mathrm{U}\right) \mathrm{UO}_{2}$, (4) $\mathrm{ThO}_{2}-\mathrm{PuO}_{2},(5) \mathrm{ThO}_{2}-\left(20 \%{ }^{235} \mathrm{U}\right) \mathrm{UO}_{2}$, (6) $\mathrm{ThO}_{2}-(41 \% 233 \mathrm{U}, 17 \% 235 \mathrm{U}) \mathrm{UO}_{2}$, and (7) $\mathrm{ThO}_{2}-(12 \% 233 \mathrm{U}, 1 \% 235 \mathrm{U}) \mathrm{UO}_{2}$. The value of the neutron multiplication factor, $k_{\infty}$, at full power operating conditions after two-thirds of goal irradiation exposure for each of the seven fuel types listed above was the criterion established to determine the fissile loading requirement for each type of fuel used in the closed cycle calculations. The average fuel exposure in a PWR just prior to the annual discharge and refueling is two-thirds of goal exposure. Thus, the value of $k_{\infty}$ for each fuel type at this condition represents the reactivity required from that fuel type if the reactor is to meet its annual fuel discharge schedule. The mixture of fissile and fertile material streams were adjusted for each different fuel to match the value of $k_{\infty}$ required from that type fuel to continue reactor operation at steady-state. This procedure determined the closed cycle fuel constituent compositions in which all the multiplerecycle fissile material had been either consumed or retired.

The effects of buildup of higher actinides are taken into account explicitly in ALTHAEA. Considerable amounts of $\mathrm{Np}$, Am, and $\mathrm{Cm}$ buildup during irradiation. These nuclides were assumed to be separated from the Th, $U$, and $P U$ streams during reprocessing as were all the fission products. Some ${ }^{241} A m$ is present in refabricated fuels containing plutonium due to the decay of ${ }^{241} \mathrm{Pu}$ that occurs after reprocessing.

Some preliminary calculations of the radiation levels in recycle fissile materials have been made. Three different types of fuels were selected for comparison: $\mathrm{LEU}, \mathrm{UO}_{2}-\mathrm{PuO}_{2}$ and $\mathrm{ThO}_{2}-\mathrm{UO}_{2}$. Fission product buildup, actinide transmutation, and radioisotope decay for these fuels were modeled with the ORIGEN ${ }^{(5)}$ computer code. The specific activities and gamma-ray spectra at various times after fuel discharge calculated by ORIGEN were used in the 
ANISN ${ }^{(6)}$ transport theory code to calculate the self-shielding of gamma radiation emitted from a $10 \mathrm{~kg}$ sphere of recovered material in the oxide form, and dose rates at different distances from the sphere. Radiation levels were analyzed for three process conditions for each fuel type:

a) when some fission products remain with the extracted heavy elements,

b) when the heavy elements are completely separated from fission products, and

c) when fresh fuel is preirradiated before it is transported from the refabrication facility. 


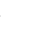




\section{IDENTIFICATION OF ALTERNATIVE CLOSED FUEL CYCLES}

With a half-life of $7 \times 10^{8}$ years, ${ }^{235} U$ is the longest lived fissile nuclide; as such it is the only naturally occurring fissile material. The ${ }^{235} \mathrm{U}$ concentration in natural uranium is enriched from $0.7 \%{ }^{235} U$ to about $3 \%{ }^{235} U$ (LEU) in order to fuel current LWRs. Alternatively, the ${ }^{235} U$ concentration could be enriched to higher levels to permit the introduction of thorium in LWR fuels. The two enrichments usually proposed for these fuels ${ }^{(7)}$ are: $\mathrm{ThO}_{2}-\left(93 \%{ }^{235} \mathrm{U}\right)$ $\mathrm{UO}_{2}$ (HEU-Th), and $\mathrm{ThO}_{2}-\left(20 \%{ }^{235} \mathrm{U}\right) \mathrm{UO}_{2}$ (DU-Th). Uranium with $\leq 20 \% 235 \mathrm{U}$ concentration is considered "denatured" because it is not useful directly as weapons material. Fuels containing HEU will have limited deployment, which means that they must be processed, transferred, or used within safeguarded sites called fuel cycle centers. ${ }^{(8)}$

Irradiation of LEU leads to the production of plutonium and the irradiation of thorium leads to the production of ${ }^{233} \mathrm{U}$. Since both of these products are fissile, they can be recovered from spent fuel and refabricated into fresh fuel. This recycling of fuel reduces the demand for both natural uranium and enrichment services. The recovered plutonium could be recycled in either uranium or thorium. Similarly, the recovered ${ }^{233} \mathrm{U}$ could be recycled in either thorium (as either HEU-Th or Du-Th) or in additional uranium. If we restrict fuel refabrication to at most binary mixtures and prohibit export of usable fissile material out of the fuel cycle, there are seven basic "closed" fuel cycles which are listed in Table 3.

Non-proliferation criteria proposed for LWR fuel cycles ${ }^{(8)}$ would require the highly enriched ${ }^{235}$ material to be fabricated into full subassemblies at the fuel cycle center where the enrichment facility is located, and further require the fuel to be spiked with gamma-ray activity which produces a dose level $\geq 1000 \mathrm{rem} / \mathrm{hr}$ at one meter if the subassembly is to leave the fuel center. Variations from Cycle 7 , also fed with $93 \%{ }^{235} U$, which employ recycle of bred ${ }^{233} \mathrm{U}$ in DU-Th or LEU were not considered because they involve large enrichment blending losses, and have less efficient use of natural resources than cycle 7 . 
TABLE 3. List of Alternative Closed Fuel Cycle Constituents Closed No. of

Fuel Cycle Fuel Types

1 
Cycle 6 probably represents the most flexibility in deployment of a11 the cycles considered. Only about a third as much plutonium is bred in Du-Th as in LEU. Thus, the amount of plutonium produced in this cycle is lower than any other cycle (except for Cycle 7). As a result, the requirements in deployment of Cycle 6 constituents inside the fuel centers are sma1ler than any other cycle. 


\section{v. ISOTOPIC MASS FLOW RATES FOR ALTERNATIVE CLOSED FUEL CYCLES}

The calculation of the isotopic mass flow rates for each of the seven basic closed fuel cycles is based on successive recycle of irradiated fuel. For each of the closed fuel cycles, a burnup calculation was performed on a 1 MT load of the primary fuel. After reprocessing, the discharge isotopics from this irradiation step, excluding fission products and the higher actinides ( $\mathrm{Np}, \mathrm{Am}$, and $\mathrm{Cm}$ ) were fabricated to form a load of the secondary fuel type. The secondary fuel was irradiated and recycled until its effective fissile content was near tails equivalent or until the recycled material contributed less than $0.5 \%$ of the total amount of energy produced by that specific fuel cycle. The fissile material generated from the secondary fuel was refabricated to form the tertiary fuet type.

The fissile loadings of all primary fuels were the same as those calculated by Combustion Engineering $(3)$ in the steady state mode. ALTHAEA was calibrated for each fuel type as described in Appendix B. This study did, however, estimate re-enrichment of the low enriched uranium (LEU) fuel to make ful1 use of a 11 the fissile ${ }^{235} \mathrm{U}$ present. The successive re-enriching of irradiated $\mathrm{UO}_{2}$ was performed until the effective fissile content was at or below tails equivalent. The increased concentrations of ${ }^{234} U$ and ${ }^{236} U$ were calculated at each enriching step using the methodology described by A. de la Garza. ${ }^{(9)}$ The fissile loadings for each component of the secondary and tertiary fuel chains were determined by adjusting the fissile content before each irradiation step such that the neutron multiplication factor, $k_{\infty}$, at $2 / 3$ of goal exposure matched the $k_{\infty}$ at $2 / 3$ goal exposure in the calibrated ALTHAEA case for the same fuel type.

Sequentially, the process of determining the mass flow rates for each fuel cycle is based on the following calculations:

- Irradiation of 1 MT of primary fuel to goal exposure.

- Reprocessing of primary fuel. 
At this point, if the primary fuel is LEU, re-enrichment is estimated. The degree of enriching at each step is determined by iteration. First, an estimate of the fissile loading is made; then a series of calculations are performed to determine the composition of that fuel after the enriching process and at that particular ${ }^{235} \mathrm{U}$ content. A burnup calculation is then performed using ALTHAEA, if $k_{\infty}$ at $2 / 3$ of goa 1 exposure matches the $k_{\infty}$ at $2 / 3$ of goal exposure in the calibrated case, then that specific composition is used as the next load. If not, the above steps are repeated until the neutron multiplication factors at $2 / 3$ goal exposure are the same. The plutonium recovered from reprocessing is then fabricated to form the first load of the secondary fuel type.

In the event the primary fuel is thorium based, the $U$, Th and Pu are recovered after the reprocessing step. The first load of the secondary fue 1 chain is then formed from the discharge isotopics of the primary fuel type, allowing the $1 \%$ loss from reprocessing and refabrication. Using ALTHAEA, perform burnup calculations to determine the fissile loading and discharge isotopics for this load. As neutron absorbers build in at each irradiation step, some fertile material has to be eliminated such that the required fissile content for that given composition of fue 1 can be met. The amount of fertile material to be eliminated at each step is estimated prior to using ALTHAEA. A check of this estimate is made after the burnup calculation is completed. This iteration step is continued until the desired $k_{\infty}$ is obtained. For this reason, each succeeding load in a chain of the same fuel type is smaller than the previous load primarily because the conversion ratio is less than unity, but also because additional fissile concentration is required to overcome neutron absorbers that have built in.

The above steps are repeated until the effective fissile content of the reprocessed material is at or below tails equivalent or until a segment load within a fuel chain contributes less than $0.1 \%$ to the total amount of energy in a particular closed cycle. 
For those closed fuel cycle systems where fissile material generated in the tertiary fuel is recycled into the secondary fuel type, the amount of recycled material. is estimated initially. This amount, plus the fissile material from the primary system, makeup the fissile loading in the first component load of the secondary chain. Successive recycle burnup chains are then calculated using ALTHAEA. The recovered fissile material then forms the first load of the tertiary fuel chain. Successive recycle burnup calculations are then made on the tertiary fuel type. The fissile material generated in this chain is checked against the initial estimate. This iteration process is repeated until the initial estimate and the amount of fissile material calculated are in good agreement.

Once all of the mass flows for a given closed fuel cycle have been calculated, the respective power contribution of each load within each chain is calculated. These individual power contributions are then summed, and normalized to 1000 MWe. This procedure permits the merits and disadvantages of each fuel cycle to be weighed against one another on a common basis.

Within each closed fuel cycle system, whether binary or tertiary, the sum of a 11 fuel loads and compositions represent a single, annual core charge, composed of the relative amounts of material present in each fuel type as portrayed in Figures 8 through 14, respectively. The sizes and compositions of these loads will be the same each year in the steady-state condition. In Appendix $C$, Figures $C-1$ through $C-7$ illustrate the same fuel cycles, but the detailed individual chains of each fuel type are represented. 

FIGURE 8:

CYCLE I - FUEL CYCLE CONSTITUENTS

LEU $(<4 \% 235 \mathrm{U}) \mathrm{UO}_{2}$ (PRIMARY)

Pu-Th $\mathrm{ThO}_{2}-\mathrm{PuO}_{2}$ (SECONDARY)

OU-Th $\mathrm{ThO}_{2}$ K $11 \%$ 233u) U0 2 (TERTIARY)

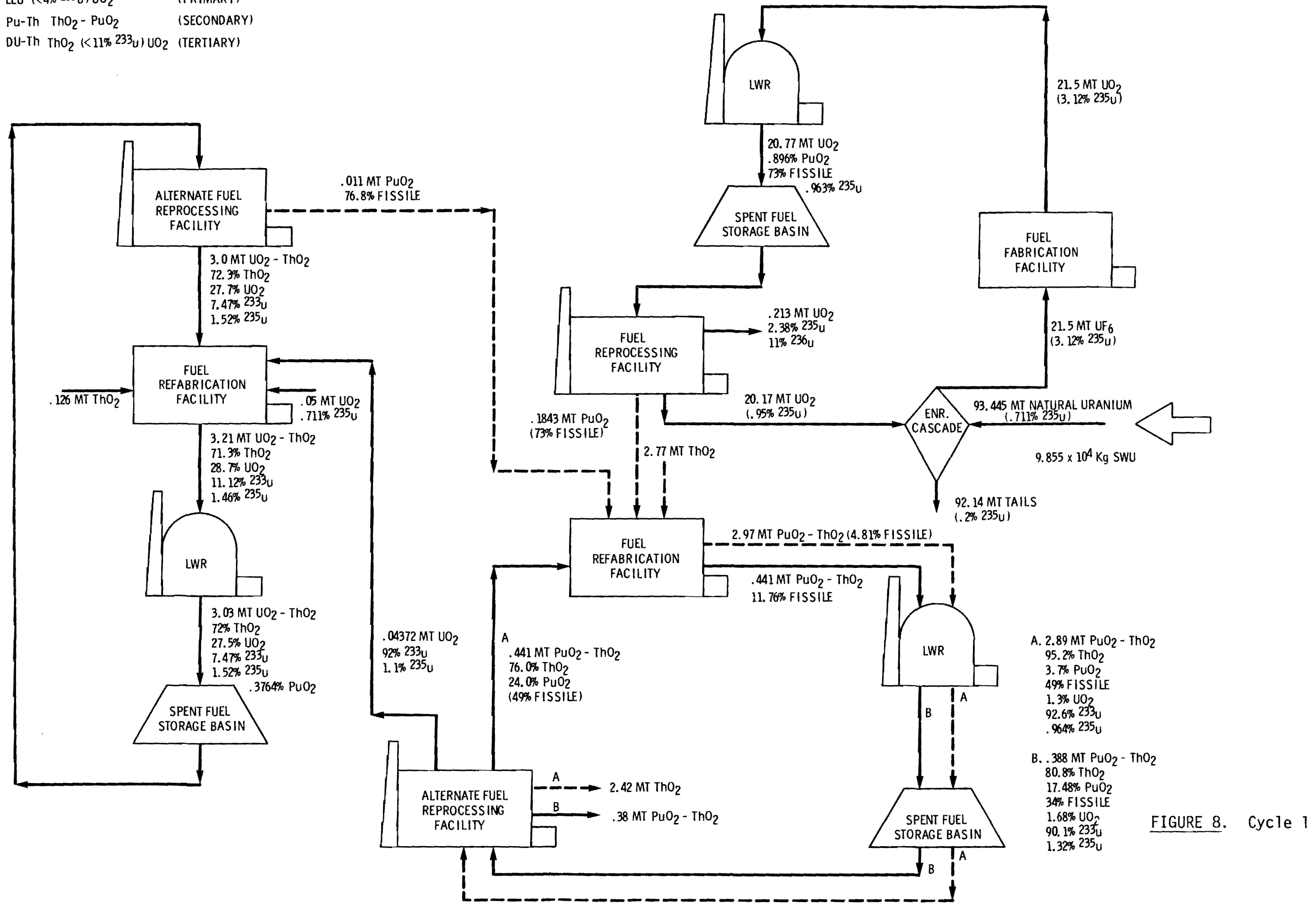


FIGURE 9 .

CYCLE 2 - rUEL CYCLE CONSTTTUENTS

LEU K4\% 235U) UO 2 (PRIMARY)

Pu-Th $\mathrm{ThO}_{2}-\mathrm{PuO}_{2}$ (SECONDARY)

LEU K3\% 233U) UO ${ }_{2}$ (IERTIARY)

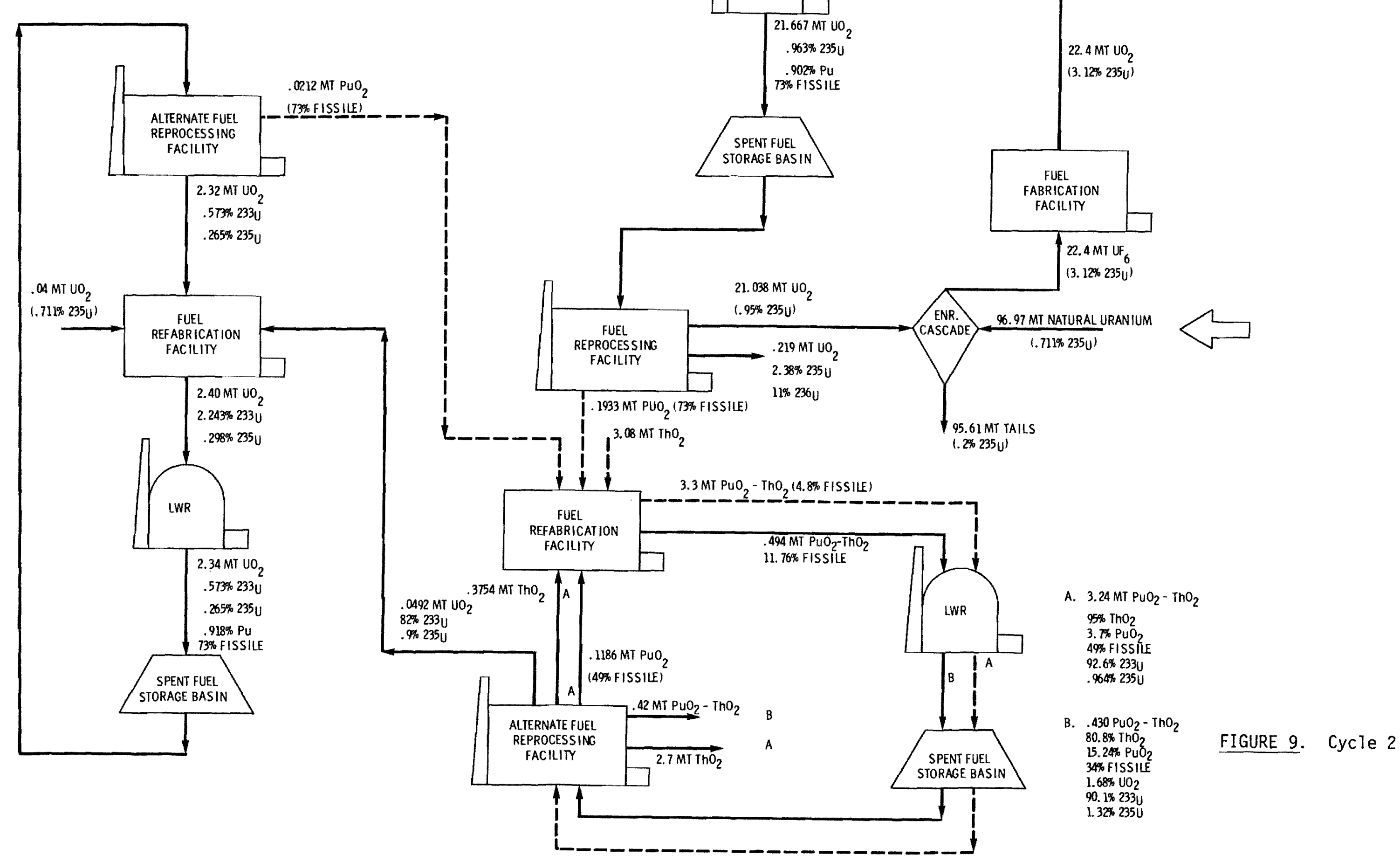




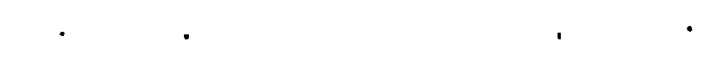



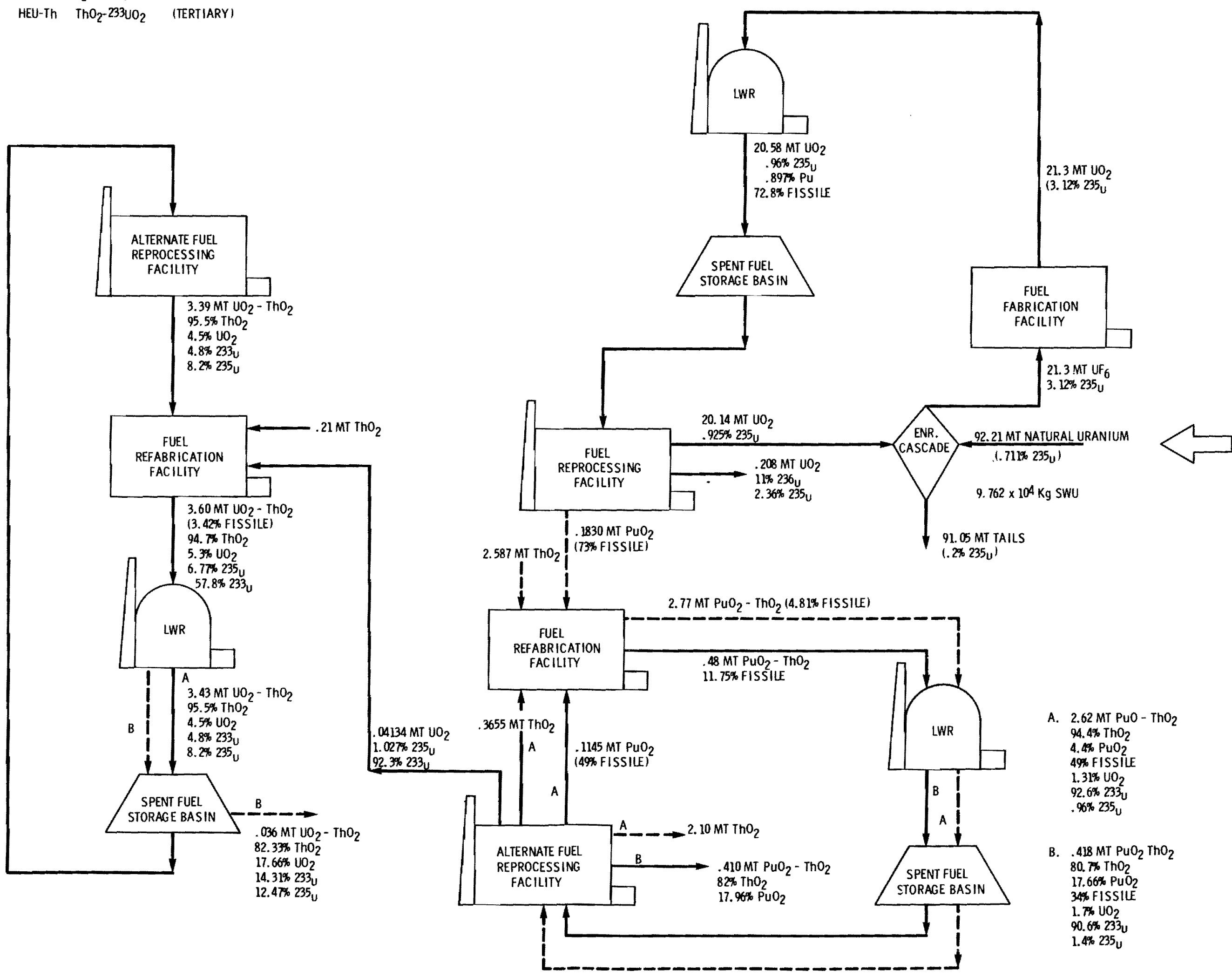

FIGURE $10 . \quad$ Cycle 3 

FIGUPE

CYCLE 4 - FUEL CYCLE CONSTITUENTS

LEU K $4 \%$ 235 ${ }^{2} / \mathrm{VO}_{2}$ (PRIMARY)

Pu-U $\mathrm{UO}_{2}-\mathrm{PUO}_{2}$ (SECONDARY)

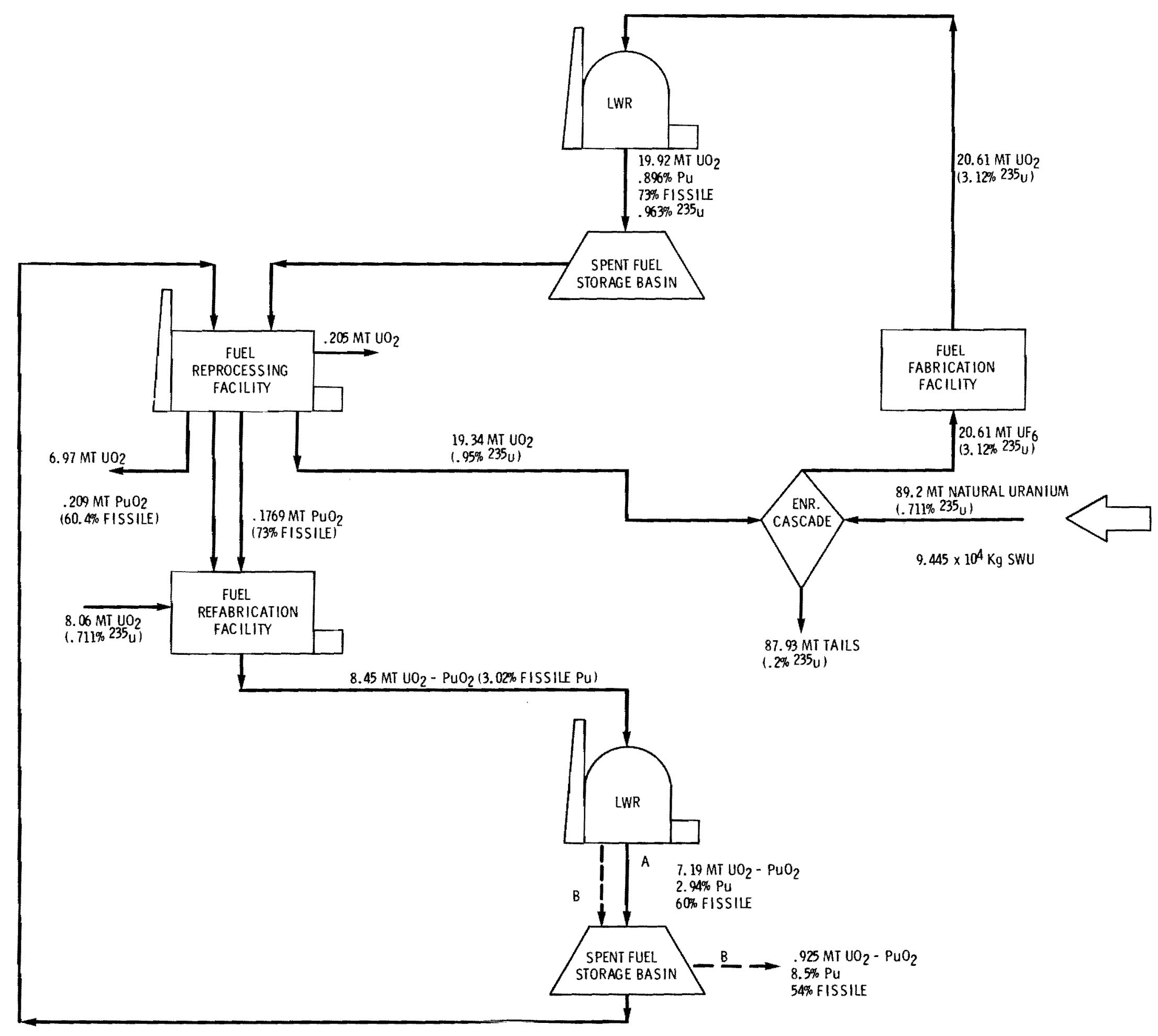

FIGURE 11. Cycle 4 

FIGURE 12:

CYCLE 5 - FUEL CYCLE CONSTITUENTS

Du-Th ThO $-200 \%$ 235 U) UO, (PRIMARY)

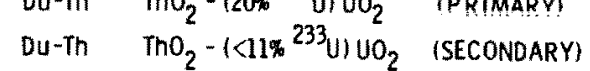

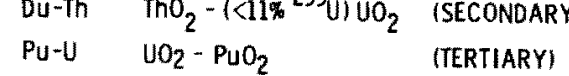
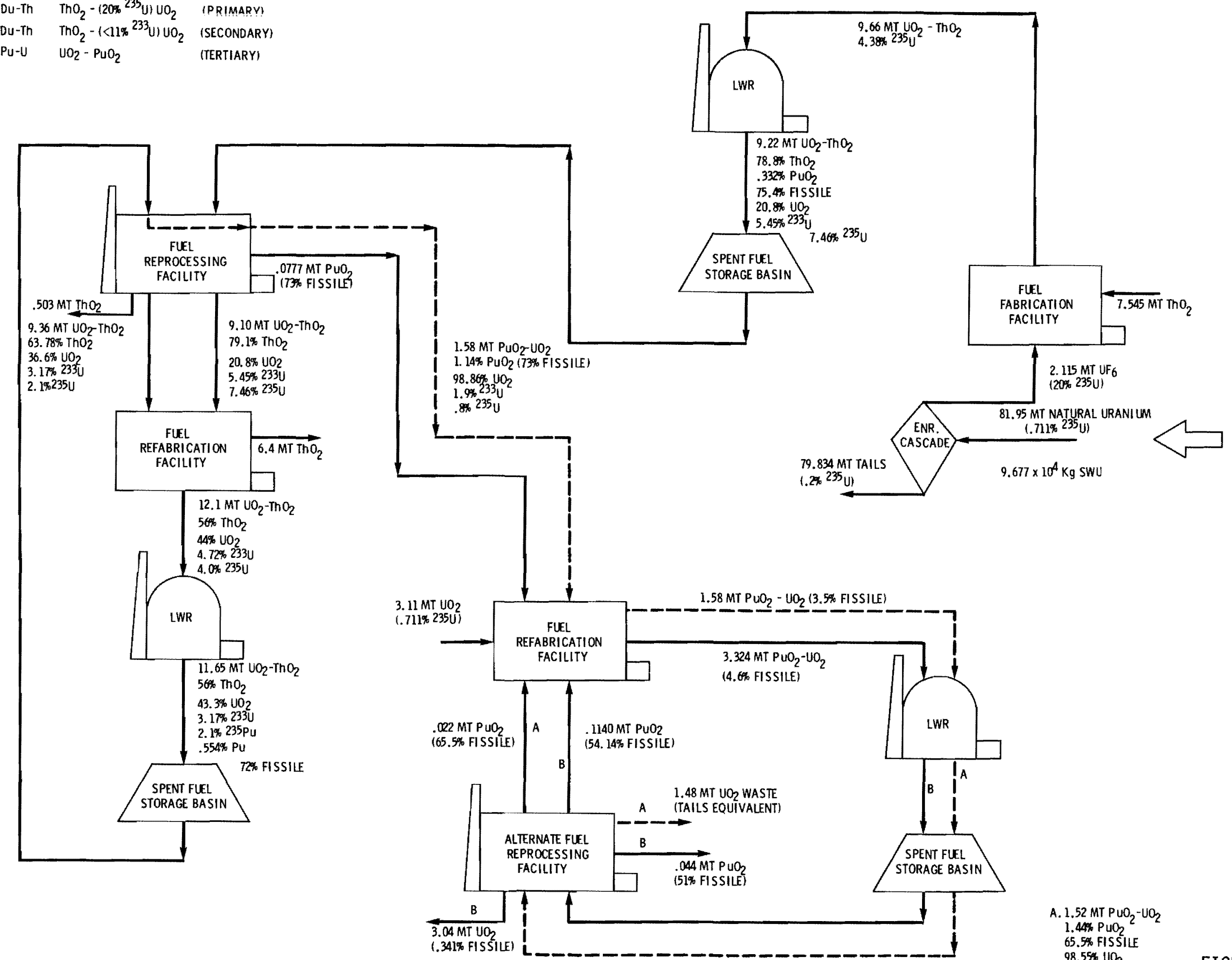

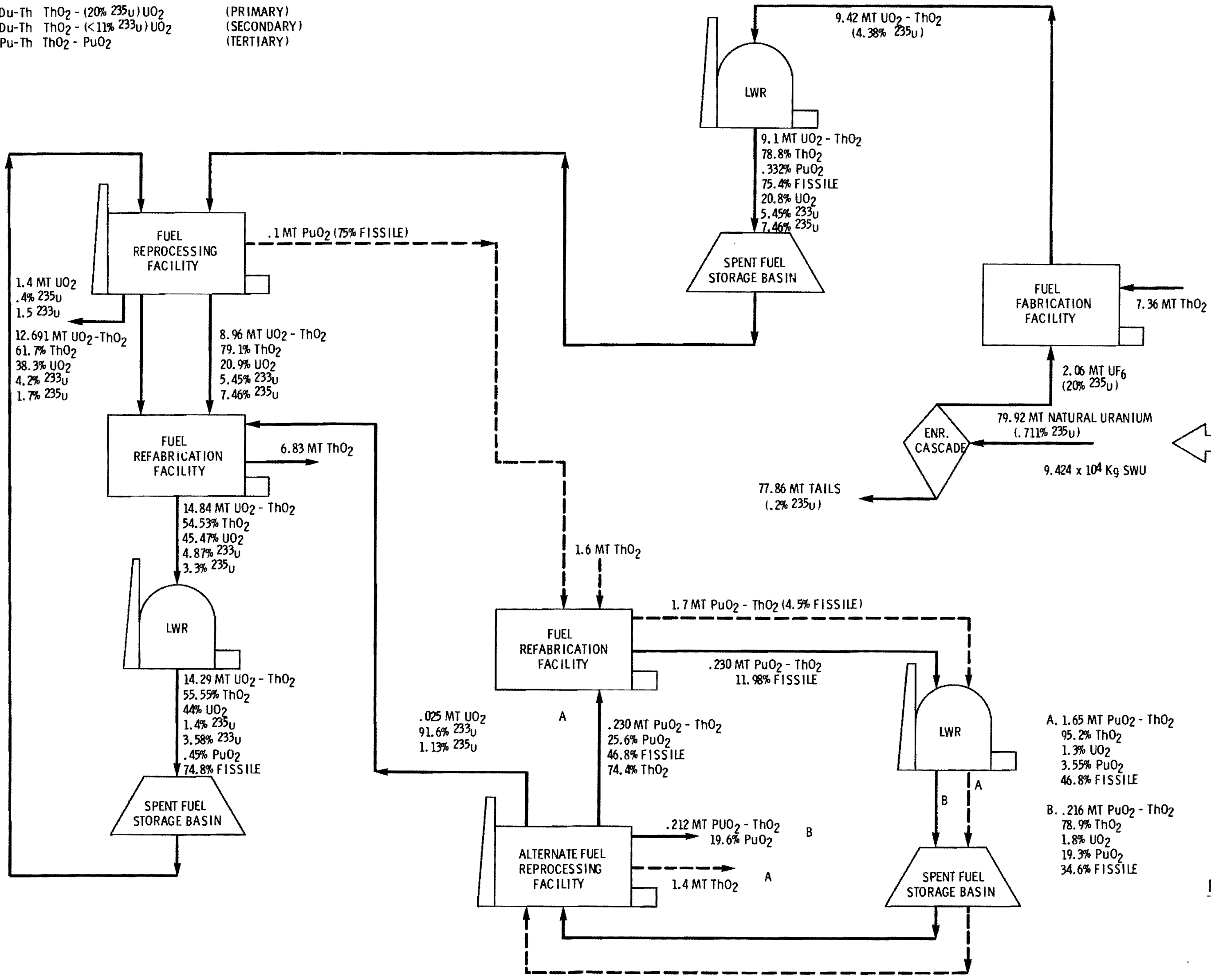

A. $1.65 \mathrm{MT} \mathrm{PuO}_{2}-\mathrm{ThO}_{2}$

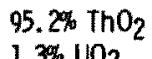

3.5.\% $\mathrm{PuO}$

$3.55 \% \mathrm{PuO}_{2}$
$46.8 \% \mathrm{FISSILE}$

B. . $216 \mathrm{MT} \mathrm{PuO}_{2}-\mathrm{ThO}_{2}$ $18 \% \mathrm{UO}_{2}$

$19.3 \% \mathrm{PuO}_{2}$

$34.6 \%$ FISSILE 
FIGURE 14:

CYCLE 7 - FUEL CYCLE CONSTITUENTS

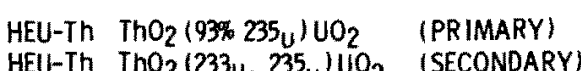

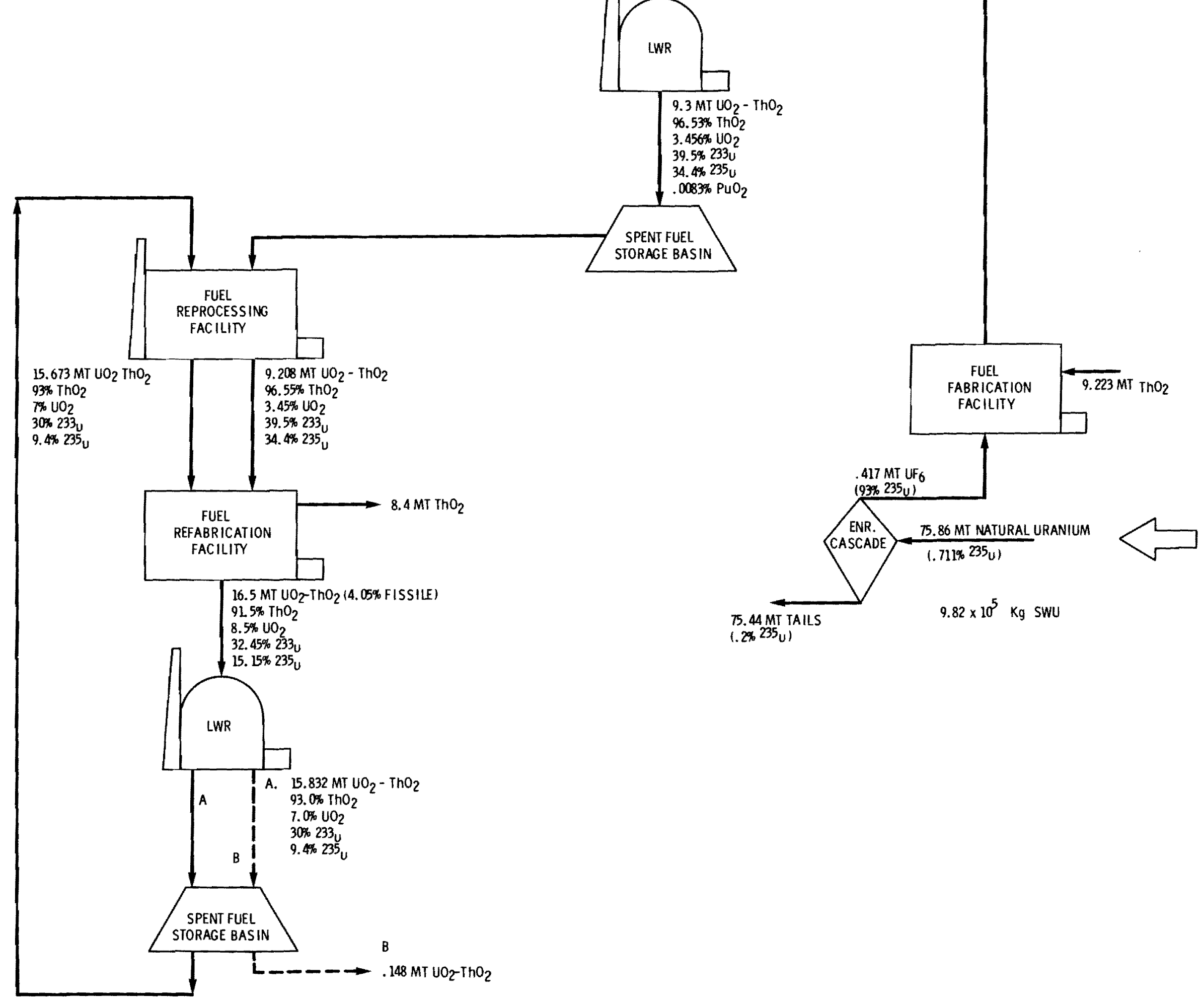

FIGURE 14. Cycle 7 


\section{RESOURCE AND ENRICHMENT DEMAND COMPARISONS}

The fractional power contributions by fuel type are shown in Table 4. Proportionately, those fuel cycles which employ LEU as the primary fuel type, rely more heavily on the primary fuel to provide the larger fraction of the 1000 MWe. In each of these cycles, plutonium is used as the fissile material for the secondary fuel type. Those fuel cycles which utilize U-Th as the primary fuel, have the largest fraction of the 1000 MWe generated in the secondary fuel type where the fissile constituents are ${ }^{233} \mathrm{U}$ and ${ }^{235} \mathrm{U}$. This indicates that in the equilibrium condition the recycle of ${ }^{233} \mathrm{U}$ is more supportive and efficient as a thermal fuel for LWRs than the recycle of plutonium. Furthermore, those cycles that utilize U-Th as primary and secondary fuels are more efficient converters of usable fissile material in LWRs.

The utilization of uranium and thorium resources for each fuel cycle can be seen in Table 5. As expected those fuel cycles that require the largest fraction of power to be generated by the primary fuel type also consume greater amounts of natural uranium.

Based on resource utilization and fractional power contributions by fuel type, Cycle 6 appears to be the most promising for long-term energy production. Cycle 7 has a slightly smaller uranium supply requirement, but a slightly higher enriching facility (SWU) demand due to the use of $93 \%$ enriched ${ }^{235} \mathrm{U}$ as compared with $20 \%$ enriched ${ }^{235} U$ in Cycle 6 . Included with the higher enriching facility demand is the fact that the $93 \%{ }^{235} \mathrm{U}$ enriched uranium must be produced, fabricated, and used in a secured center. ${ }^{(8)}$ This requirement severely limits deployment of that cycle and future reactor siting.

Additionally, Cycle 6 has the lowest fraction of power produced by a fuel type within a secured center. Plutonium in the tertiary fuel would have to be used within a secured center unless it was spiked, but it represents only about $7 \%$ of the power generated. However, Cycles 5 and 6 are the most complicated and thus may be the most expensive. The secondary fuel type would actually be 
TABLE 4. Fractional Power Generation by Fuel Type

Power Generated

by Fuel Type

Cycle Type of

No. Enriched U Feed Fuel Composition

in a 1000 MWe System

(MWe)

1

$\left(3.12 \%{ }^{235} \mathrm{U}\right) \mathrm{UO}_{2} \begin{cases}\mathrm{ThO}_{2}-\mathrm{PuO}_{2} & 131\end{cases}$

746

123

$\left(\begin{array}{lll}(<4 \% & 235 \\ \mathrm{U}\end{array}\right) \mathrm{UO}_{2}$

2

$\left(3.12 \%{ }^{235} \mathrm{U} \mathrm{UO}_{2} \begin{cases}\mathrm{ThO}_{2}-\mathrm{PuO}_{2} & 143\end{cases}\right.$

$\left(<3 \%{ }^{233} \mathrm{U}\right) \mathrm{UO}_{2}$

81

$3 \quad\left(3.12 \%{ }^{235} \mathrm{U}\right) \mathrm{UO}_{2} \begin{cases}\left(<4 \%{ }^{235} \mathrm{U}\right) \mathrm{UO}_{2} & 739 \\ \mathrm{ThO}_{2}-\mathrm{PuO}_{2} & 124 \\ \mathrm{ThO}_{2}-\left(<11 \%{ }^{233} \mathrm{U}\right) \mathrm{UO}_{2} & 137\end{cases}$

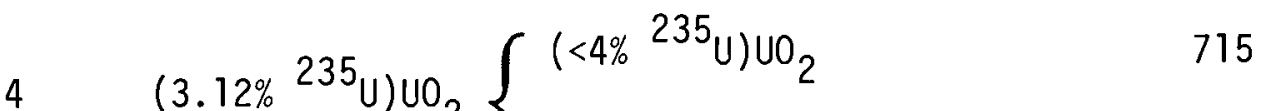

$4 \quad\left(3.12 \%{ }^{235}\right) \mathrm{UO}_{2} \begin{cases}\left(\mathrm{UO}_{2}-\mathrm{PuO}_{2}\right. & 285\end{cases}$

$5 \quad\left(20 \%{ }^{235} \mathrm{U}\right) \mathrm{UO}_{2} \begin{cases}\mathrm{ThO}_{2}-\left(20 \%{ }^{235} \mathrm{U}\right) \mathrm{UO}_{2} & 368 \\ \mathrm{ThO}_{2}-\left(11 \%{ }^{235} \mathrm{U}\right) \mathrm{UO}_{2} & 461 \\ \mathrm{UO}_{2}-\mathrm{PuO}_{2} & 171\end{cases}$

$6 \quad\left(20 \%{ }^{235} \mathrm{U}_{2}\right) \mathrm{O}_{2}\left\{\begin{array}{lr}\mathrm{ThO}_{2}-\left(20 \%{ }^{235} \mathrm{U}^{2} \mathrm{UO}_{2}\right. & 360 \\ \mathrm{ThO}_{2}-\left(11 \%{ }^{233} \mathrm{U}_{2} \mathrm{UO}_{2}\right. & 566 \\ \mathrm{ThO}_{2}-\mathrm{PuO}_{2} & 74\end{array}\right.$

$7 \quad\left(3 \%{ }^{235} U\right) \mathrm{UO}_{2} \quad \begin{cases}\mathrm{ThO}_{2}-\left(93 \%{ }^{235} U\right) \mathrm{UO}_{2} & 368 \\ \mathrm{ThO}_{2}-\left({ }^{233} \mathrm{U},{ }^{235} \mathrm{U}\right) \mathrm{UO}_{2} & 632\end{cases}$ 
TABLE 5. Resource and SWU Requirements

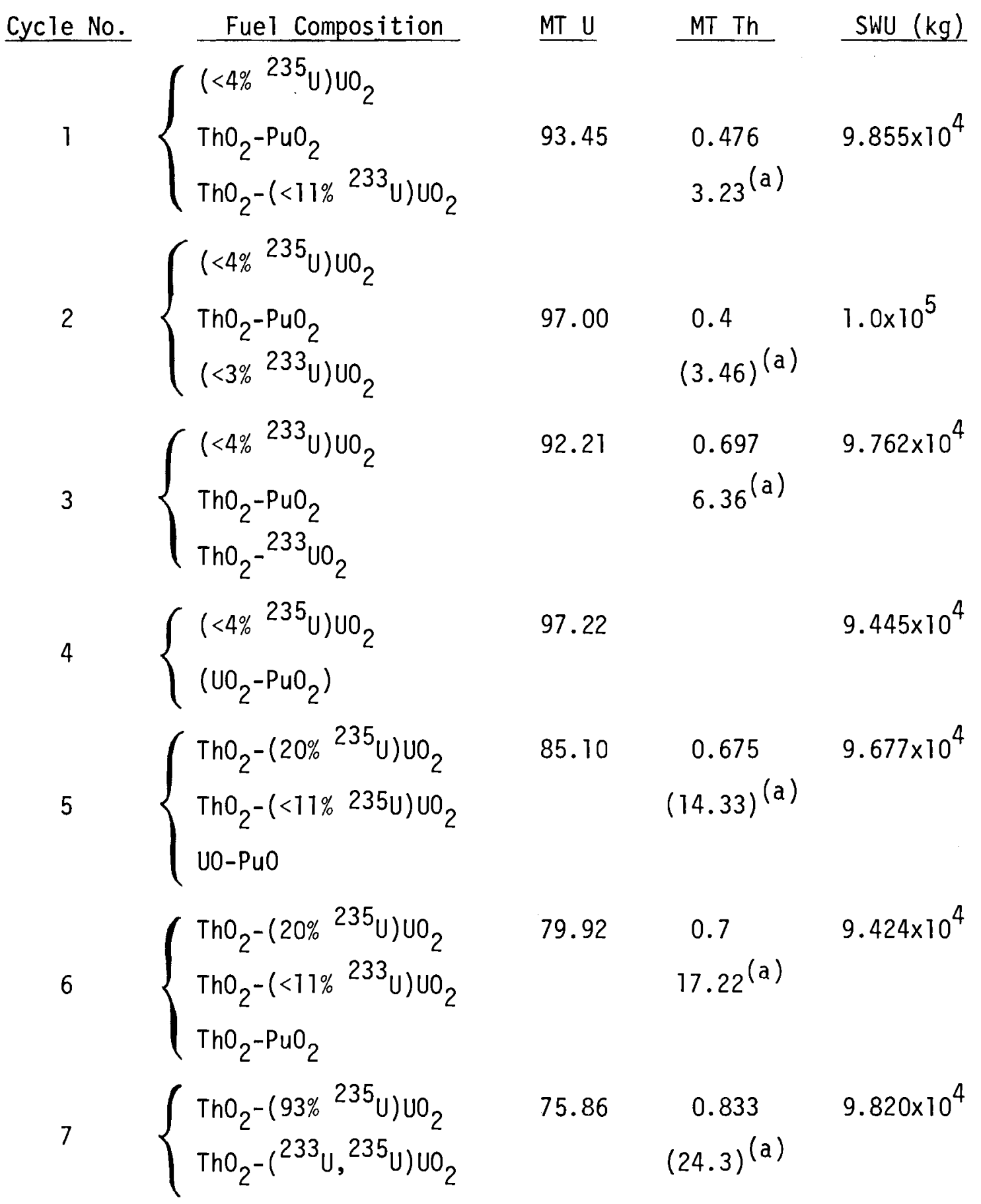

(a) No Thorium Recycle. 
treated as four or five separate fuel types for purposes of fabrication and irradiation. Campaign reprocessing would also be necessary for this cycle for purposes of isolating the uranium to be retired from the cycle. Each part of a fuel chain must be reprocessed separately so that as the uranium composition is equal to or below tails fissile equivalent the uranium can be "retired" to waste. 


\section{RADIATION LEVELS FROM SELECTED FUELS}

Two methods for producing a more diversion-resistant fuel are preirradiation of fresh fuel and incomplete separation of fission products in the recovery of fuel through reprocessing of spent fuel. Both these methods will result in significant dose rates from the fuel and may serve as a deterrent to the diversion of fissile material.

The lengths of time these approaches will serve to deter diversion efforts were compared for generically different fuel types by calculating dose rates as a function of decay time. One reprocessing scheme assumed a CIVEX ${ }^{(10)}-1$ ike separation process following goal burnup of the fuel in which some fission products remain with the extracted heavy elements. This scheme was compared with others which separate all of the fission products from the heavy elements, in order to determine the increase in dose rates resulting from the retention of some fission products. For the pre-irradiation cases, small amounts of fuel burnup were assumed to occur over a one month period following fuel fabrication. Dose rates were again compared for the different fuel types.

\section{REPROCESSED FUEL}

Three reprocessing schemes were considered: (1) a process whereby only thorium, uranium and plutonium are recovered, (2) a process whereby the transuranic elements ( $\mathrm{Np}, \mathrm{Am}, \mathrm{Cm}$ ) are retained with the thorium, uranium, and plutonium, and (3) a CIVEX-1ike process in which $100 \%$ of the fission products $\mathrm{Zr}$ and $\mathrm{Nb}$ and $15 \%$ of the fission product $\mathrm{Ru}$ remain with the extracted heavy elements. A11 reprocessing was assumed to occur after a cooling time of 300 days; thus no dose rate calculations were performed for times shorter than this.

Three generic fuel types for LWR's were compared: low-enriched ${ }^{235} \mathrm{UO}_{2}$ fuel, $\mathrm{PuO}_{2}$-natural $\mathrm{UO}_{2}$, and a $\mathrm{ThO}_{2}-{ }^{233} \mathrm{UO}_{2}$ fuel. These are fuel types 1,2 and 6 , respectively, from the NASAP candidate fuel types of Reference 4 . Initial 
TABLE 6. Initial Fuel Compositions

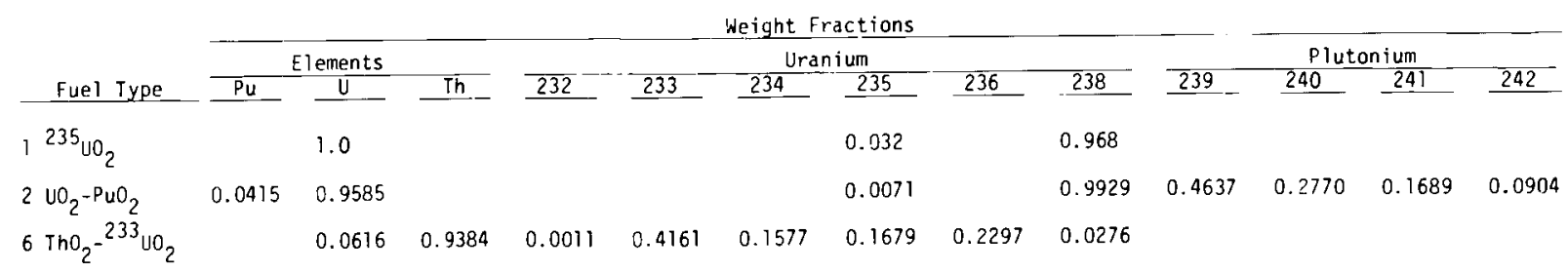

\section{TABLE 7. Discharge Fuel Compositions}

\begin{tabular}{|c|c|c|c|c|c|c|c|c|c|c|c|c|c|c|}
\hline \multirow[b]{2}{*}{ _Fuel Iype } & \multicolumn{9}{|c|}{ 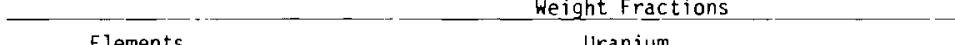 } & \multirow{2}{*}{\multicolumn{5}{|c|}{ Plutonium }} \\
\hline & $P_{u}$ & $\begin{array}{l}\text { lements } \\
U\end{array}$ & Th & 232 & 233 & $\frac{\text { Uran }}{-234}$ & 235 & 236 & 238 & 238 & $239^{-}$ & & $2: 1$ & 242 \\
\hline $1^{235} \mathrm{UO}_{2}$ & 0.0095 & 0.9905 & & & & & 0.0085 & 0.0042 & 0.9874 & 0.0155 & 0.5497 & 0.2393 & 0.1421 & 0.0532 \\
\hline $2 \mathrm{UO}_{2}-\mathrm{PuO}_{2}$ & 0.0331 & 0.9669 & & & & & 0.0034 & 0.0008 & 0.9957 & 0.0109 & 0.3585 & 0.3050 & 0.1865 & 0.1399 \\
\hline $6 \mathrm{ThO}_{2}-{ }^{233} \mathrm{HO}_{2}$ & 0.0011 & 0.0501 & 0.9438 & 0.0013 & 0.3506 & 0.1902 & 0.1076 & 0.2552 & 0.0344 & 0.8632 & 0.1113 & 0.0170 & 0.0105 & 0.0014 \\
\hline
\end{tabular}


fuel compositions, as charged to the reactor, are shown in Table 6 and were obtained from Reference 4. Discharge fuel compositions are shown in Table 7 and were calculated using the ORIGEN ${ }^{(5)}$ code. Neutron spectral parameters and cross-sections were adjusted in ORIGEN to produce reasonable agreement with discharge compositions calculated by Combustion Engineering for a PWR and reported as NASAP reference data. (4) A goal burnup of 33 GWD/metric ton of heavy element was assumed in all cases; radionuclide buildup and subsequent decay were calculated using the ORIGEN code, providing gamma source strengths in several energy groups for decay times of up to 1500 days.

The recovered fuel was considered to be in the form of an oxide, formed into a sphere containing $10 \mathrm{~kg}$ of heavy elements at a density of $2.5 \mathrm{~g}$ heavy element per $\mathrm{cm}^{3}$. The sphere is thus slightly less than $10 \mathrm{~cm}$ in radius. Sphere compositions are given in Table 8 . Source strengths and gamma spectra from ORIGEN were input to the ANISN ${ }^{(6)}$ code, which calculated dose rates at 1 meter from the surface of the sphere for each fuel type, reprocessing scheme, and decay time. The dose rates thus calculated were divided by the amount of fissile material present for each case to obtain dose rates per $\mathrm{kg}$ of fissile material.

This latter quantity is of importance in determining the effectiveness of the diversion deterrence for each reprocessing scheme; a dose rate at 1 meter of $100 \mathrm{R} / \mathrm{hr}$ per $\mathrm{kg}$ of fissile material is considered to be a sufficient deterrent. (11)

Figure 15 shows the dose rates per $\mathrm{kg}$ of fissile material for the three fuel types for the case in which only thorium, uranium, and plutonium are recovered during reprocessing. Figure 16 presents dose rates per $\mathrm{kg}$ fissile material for the case in which the transuranics ( $\mathrm{Np}, \mathrm{Am}, \mathrm{Cm}$ ) are retained with the thorium, uranium, and plutonium. Note that the plots for fuel type 6 in Figures 15 and 16 are identical, since the transuranics contribute negligibly to the dose rate for this fuel type. The dose rates per $\mathrm{kg}$ fissile material for the CIVEX-1ike reprocessing case are shown in Figure 17. Since reprocessing is assumed to occur at a decay time of 300 days, no dose rates were calculated for time before this. 
TABLE 8. Sphere Compositions. 33 GWD/Metric

Ton Burnup, CIVEX Reprocessing

\begin{tabular}{|c|c|c|c|c|}
\hline Fue1 Type & Element & $\begin{array}{l}\text { Quantity(a) } \\
\text { (gms) }\end{array}$ & $\begin{array}{l}\text { Fissile } \\
\text { Nuclide }\end{array}$ & $\begin{array}{l}\text { Quantity (a) } \\
\text { (gms) }\end{array}$ \\
\hline \multirow{6}{*}{$1: \quad \mathrm{UO}_{2}$} & U & 9858 & \multirow{3}{*}{$\begin{array}{l}{ }^{235} \mathrm{U} \\
{ }^{239} \mathrm{Pu} \\
{ }^{241} \mathrm{Pu}\end{array}$} & 84 \\
\hline & $\mathrm{Pu}$ & 95 & & 53 \\
\hline & $\mathrm{Zr}$ & 38 & & 13 \\
\hline & $\mathrm{Np}$ & 5 & \multirow{3}{*}{ Tota 1} & 150 \\
\hline & Ru & 4 & & \\
\hline & 0 & 1330 & & \\
\hline \multirow{7}{*}{ 2: $\quad \mathrm{UO}_{2}-\mathrm{PuO}_{2}$} & U & 9710 & \multirow{3}{*}{$\begin{array}{l}{ }^{235} \mathrm{U} \\
{ }^{239} \mathrm{Pu} \\
{ }^{241} \mathrm{Pu}\end{array}$} & 32 \\
\hline & $\mathrm{Pu}$ & 228 & & 120 \\
\hline & $\mathrm{Zr}$ & 30 & & 59 \\
\hline & Am & 24 & \multirow[t]{4}{*}{ Tota 1} & 211 \\
\hline & $\mathrm{Ru}$ & 4 & & \\
\hline & $\mathrm{Np}$ & 1 & & \\
\hline & 0 & 1330 & & \\
\hline \multirow{6}{*}{ 6: $\mathrm{ThO}_{2}-\mathrm{UO}_{2}$} & Th & 9197 & \multirow{3}{*}{$\begin{array}{l}{ }^{233} \mathrm{U} \\
{ }^{235} \mathrm{U} \\
{ }^{239} \mathrm{Pu}\end{array}$} & 186 \\
\hline & U & 749 & & 84 \\
\hline & $\mathrm{Zr}$ & 45 & & 1 \\
\hline & $\mathrm{Np}$ & 14 & \multirow[t]{3}{*}{ Tota 1} & \multirow[t]{3}{*}{271} \\
\hline & Ru & 2 & & \\
\hline & 0 & 1330 & & \\
\hline
\end{tabular}

(a) To nearest gram; oxygen to nearest 10 grams. Other elements are present in trace quantities. Quantity is at time of reprocessing (300 days decay). 
Comparison of Figures 15 and 16 will show that $\mathrm{Np}$, Am, and $\mathrm{Cm}$ are important contributors to the dose rate for both $\mathrm{UO}_{2}-\mathrm{PuO}_{2}$ spent fuels, relative to the contributions from uranium and plutonium alone. The curve for fuel type 6 $\left(\mathrm{ThO}_{2}-\mathrm{UO}_{2}\right)$ is unaffected by the inclusion of the transuranics since most of the dose rate arises from ${ }^{232} U$ decay products. Note that none of the dose rate from recovered fuel mixtures after complete separation of fission products (shown in Figures 15 and 16) attains the $100 \mathrm{R} / \mathrm{hr}$ per $\mathrm{kg}$ fissile material deterrence criteria discussed above.

Figure 17 presents dose rates per $\mathrm{kg}$ fissile material when some fission products are retained with the heavy elements. In this case, fuel type 6 $\left(\mathrm{ThO}_{2}-\mathrm{UO}_{2}\right)$ provides significantly lower dose rates than either fuel type 1 or 2; fuel type $2\left(\mathrm{UO}_{2}-\mathrm{PuO}_{2}\right)$ gives rise to the highest dose rates. These variations result primarily from differences in the fission yield of ruthenium from ${ }^{233} U$ in comparison with those from ${ }^{235} U$ or plutonium. As can be seen, there are times for which the $100 \mathrm{R} / \mathrm{hr}$ deterrence criterion is met; for fuel types 1 , 2 and 6 , these times are approximately 500 days, 700 days, and 350 days, respective1y.

Figures 18,19 , and 20 are corresponding results for a $10 \mathrm{~kg}$ sphere of the fuel compositions recovered from the spent fuel. The dose rate calculations were performed using the ANISN code. The quantity of fissile material in $10 \mathrm{~kg}$ of recovered fuel was divided into the calculated dose rates to produce the curves for the first three figures. Dose rates at a distance of 6 inches were also calculated. These dose rates are 19.5 times higher than those at 1 meter, because of the large solid angle the sphere subtends 6 inches from its surface.

\section{PRE-IRRADIATED FUEL}

As with the reprocessing cases, three initial fuel compositions presented in Table 6 were considered. Small amounts of burnup in an LWR were assumed to occur over a 30-day period. Two burnup schemes were considered: (1) a 1\% burnup ( $330 \mathrm{MWD} / \mathrm{metric}$ ton of heavy element charged to the reactor) and 
(2) a $0.1 \%$ burnup. Since the assumed power densities are low, these irradiations could probably be performed in a natural-convection cooled water basin.

Using the same procedure as for the reprocessed fuel at full burnup, gamma source strengths and spectra calculated in ORIGEN were used in ANISN to calculate dose rates from a $10 \mathrm{~kg}$ sphere of heavy element oxides. Due to the small amounts of burnup, the compositions of the irradiated heavy element materials were virtually identical to the initial fuel compositions charged to the reactor. The fission products during irradiation provided the dominant gamma sources.

Dose rates were calculated at a distance 1 meter from the surface of the sphere. Figures 21 and 22 show the dose rates per $\mathrm{kg}$ of fissile material for pre-irradiation burnups of $1 \%$ and $0.1 \%$, respectively. As expected, dose rates for a $1 \%$ burnup are 10 times those for the $0.1 \%$ burnup, since at these low exposures fission product buildup is nearly linear function of burnup, and the power level was proportional to the chosen burnup. Decay times ranged from 0 to 1500 days.

As seen in Figures 21 and 22, dose rates from the three types of fuel are similar for a given amount of pre-irradiation. The $100 \mathrm{R} / \mathrm{hr}$ per $\mathrm{kg}$ fissile material diversion deterrence criterion is met for all three types of fuel at about 300 days for the $1 \%$ burnup scheme, and at about 80 days for the $0.1 \%$ burnup scheme. Fuel type $2\left(\mathrm{UO}_{2}-\mathrm{PuO}_{2}\right)$ provides the highest dose rates, with fuel type $6\left(\mathrm{ThO}_{2}-\mathrm{UO}_{2}\right)$ giving the lowest dose rates. This is due to the differing fission product yields of ${ }^{233} \mathrm{U},{ }^{235} \mathrm{U}$, and plutonium. Figures 23 and 24 show the dose rates from the $10 \mathrm{~kg}$ sphere of pre-irradiated fuel.

The results of the study of dose rates from the three selected fuels are summarized in Table 9. The time prior to which the $100 \mathrm{R} / \mathrm{hr}$ diversion deterrence criterion is met is given for each fuel type and reprocessing or preirradiation scheme. For reprocessed fuels, the important figure is the time after fuel refabrication, which is completed 90 days after reprocessing or 390 days after discharge from reactor. Pre-irradiation fuel is refabricated 
TABLE 9. Times Prior to Which a $100 \mathrm{R} / \mathrm{hr}$ per $\mathrm{kg}$ Fissile Material Diversion Deterrence Criterion Is Met for Selected Fuels and Various Reprocessing and Pre-Irradiation Schemes

Reprocessing or Pre-Irradiation Scheme Only $U$, Pu and Th extracted

$\mathrm{U}, \mathrm{Pu}$, and transuranics ( $\mathrm{Np}, \mathrm{Am}, \mathrm{Cm}$ ) extracted

$\mathrm{U}$, Pu, transuranics, $15_{.0}^{\circ}$ of $\mathrm{Ru}$, and $100 \%$ of $\mathrm{Zr}$ and $\mathrm{Nb}$ extracted
Times Prior to Which Criterion Is Met

\begin{tabular}{|c|c|c|}
\hline $\begin{array}{l}\text { Fue1 } \\
\text { Type }\end{array}$ & Time after Irradiation & $\begin{array}{c}\text { Time after } \\
\text { Refabrication of Fuel }\end{array}$ \\
\hline 1 & Criterion never met ${ }^{(a)}$ & Criterion never met \\
\hline 2 & Criterion never met ${ }^{(a)}$ & Criterion never met \\
\hline 6 & Criterion never met ${ }^{(a)}$ & Criterion never met \\
\hline 1 & Criterion never met ${ }^{(a)}$ & Criterion never met \\
\hline 2 & Criterion never met ${ }^{(a)}$ & Criterion never met \\
\hline 6 & Criterion never met ${ }^{(a)}$ & Criterion never met \\
\hline 1 & 500 days & 110 days \\
\hline 2 & 700 days & 310 days \\
\hline 6 & 350 days & Criterion never met \\
\hline 1 & 300 days & (c) \\
\hline 2 & 300 days & \\
\hline 6 & 300 days & \\
\hline 1 & 80 days & (c) \\
\hline 2 & 80 days & \\
\hline 6 & 80 days & \\
\hline
\end{tabular}

(a) Reprocessing occurs at 300 days after discharge from reactor - no times before this are considered for reprocessed fuels.

(b) Fuel refabrication is completed 90 days after reprocessing, which occurs at 300 days decay time.

(c) Pre-irradiated fuels are refabricated before irradiation; thus time after irradiation is the relevant quantity. 
before irradiation; therefore, the time after irradiation is the crucial quantity. In all cases the criterion could not be met unless some fission products are retained in the product stream. Even with the inclusion of some fission products, fuel type 6 would decay to too low a dose rate by the time refabrication is completed. Pre-irradiation of fresh fuels will meet the criterion for a length of time that depends on the amount of pre-irradiation. Of the reprocessing or pre-irradiation schemes that do meet the stated criterion, the type 2, $\left(\mathrm{UO}_{2}-\mathrm{PuO}_{2}\right)$ fuel usually has the highest dose rates per $\mathrm{kg}$ fissile material, followed in order of decreasing dose rate by type $1\left(\mathrm{UO}_{2}\right)$ and type $6\left(\mathrm{ThO}_{2}-\mathrm{UO}_{2}\right)$. However, at long times (several years) after refabrication the dose rate from the $\mathrm{ThO}_{2}-\mathrm{UO}_{2}$ is the highest because the short-lived contributors to the dose rates in the other fuels wi 11 have decayed and the ${ }^{232} \mathrm{U}$ decay daughter concentrations in the $\mathrm{ThO}_{2}-\mathrm{UO}_{2}$ fuel will rema in substantially unchanged. 


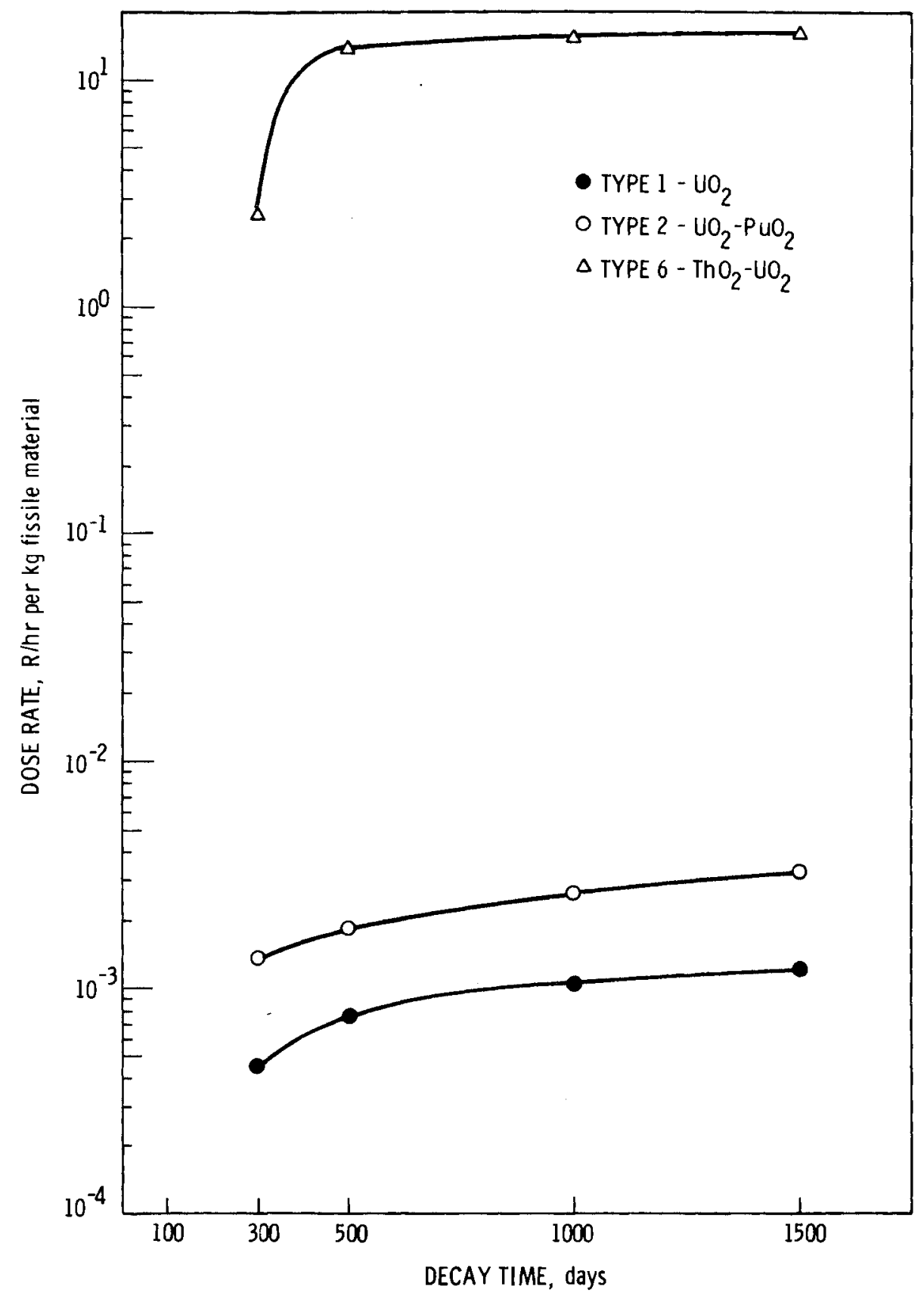

FIGURE 15. Dose Rates per kg Fissile Material at One Meter from $10 \mathrm{~kg}$ Sphere of Recovered Fuel after Fue1 Burnup with Complete Separation of Fission Products and Transuranics $(\mathrm{Np}, \mathrm{Am}, \mathrm{Cm})$ at Time of Reprocessing 


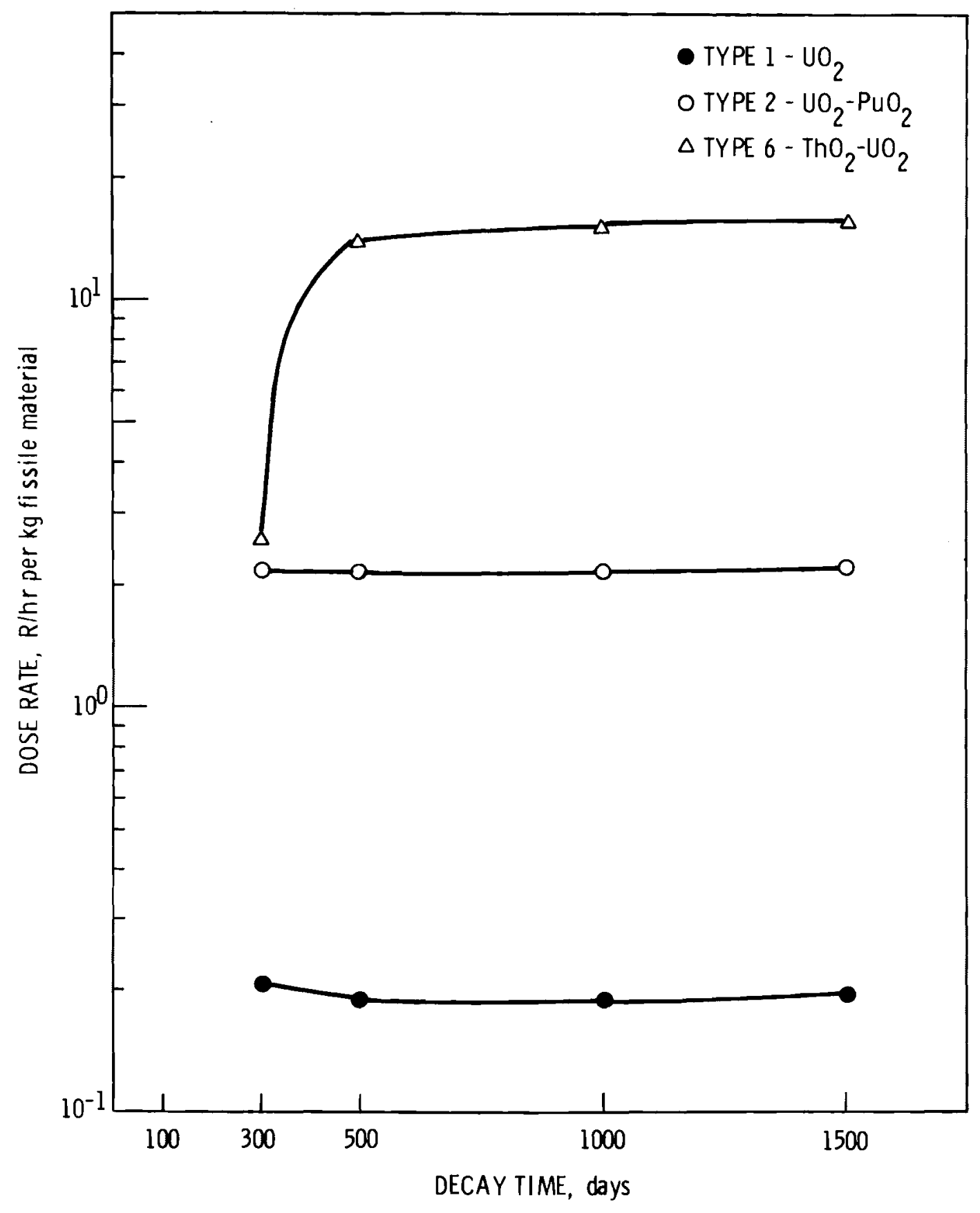

FIGURE 16. Dose Rates per kg Fissile Material at One Meter from $10 \mathrm{~kg}$ of Recovered Fuel after Fu11 Burnup with Complete Separation of Fission Products at Time of Reprocessing 


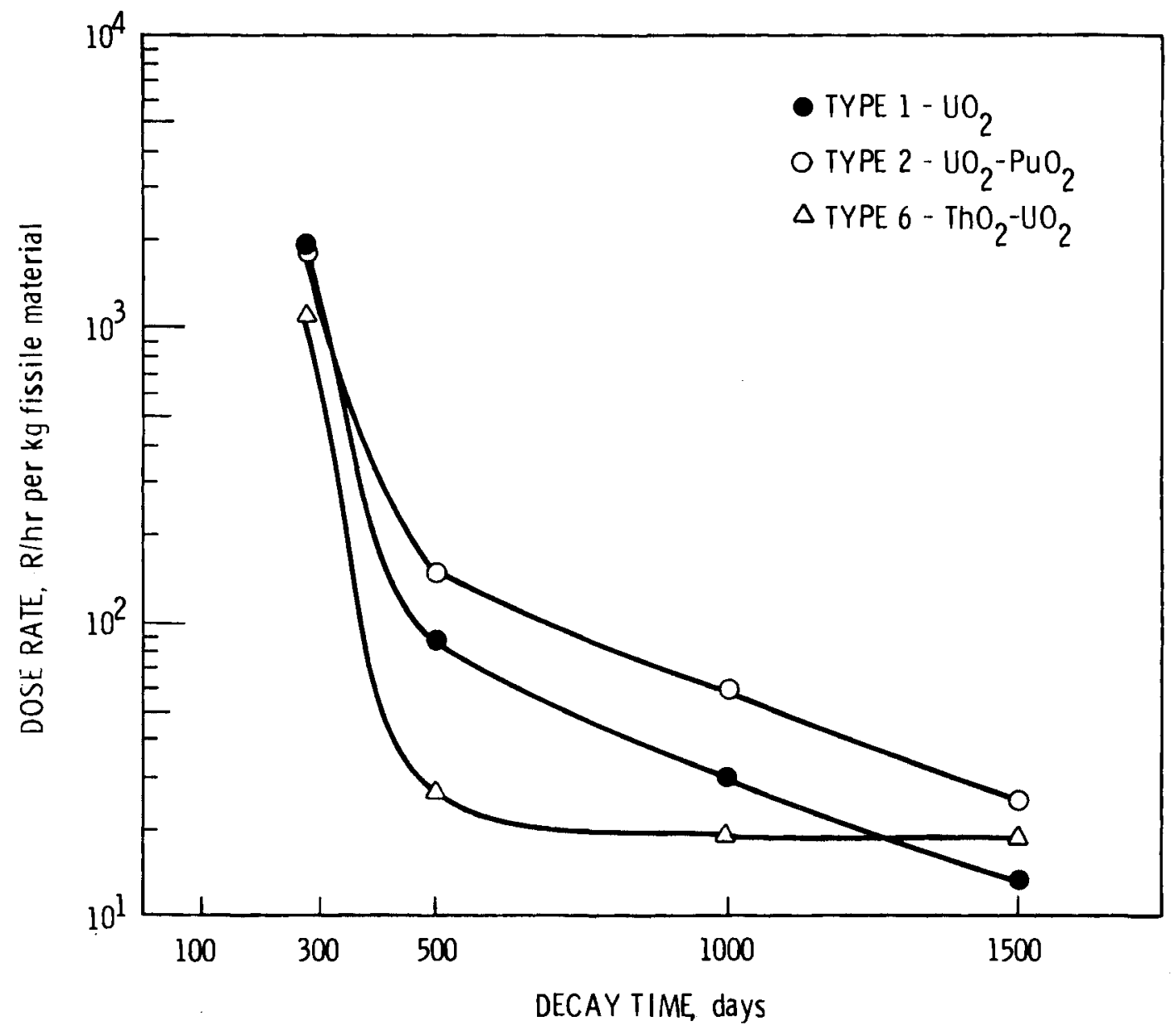

FIGURE 17. Dose Rates per kg Fissile Material at One Meter from $10 \mathrm{~kg}$ Sphere of Fuel, with CIVEX Separation of Fission Products 


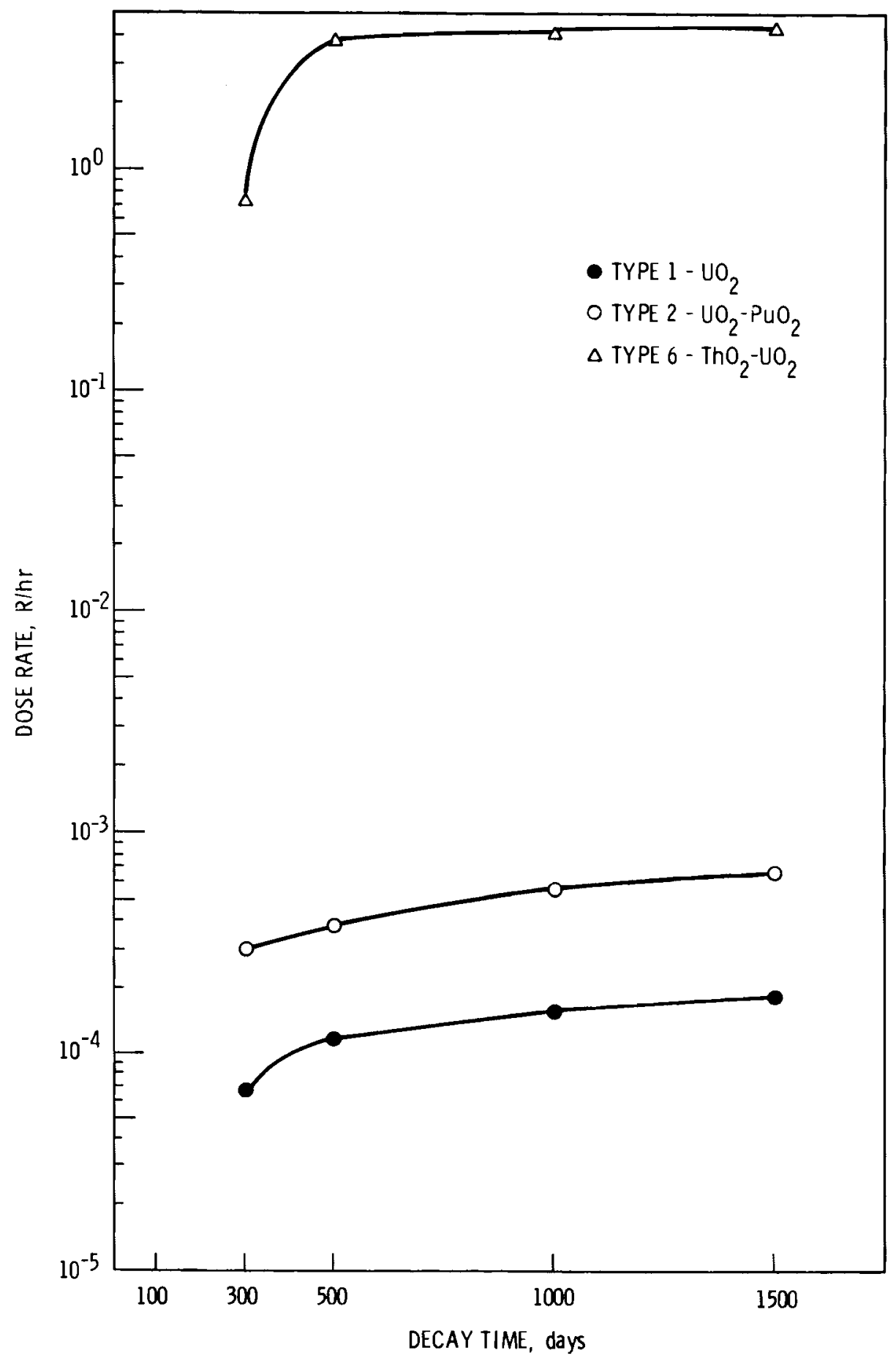

FIGURE 18. Dose Rates at One Meter from $10 \mathrm{~kg}$ Sphere of Recovered Fuel after Ful1 Burnup with Complete Separation of Fission Products and Transuranics ( $\mathrm{Np}, \mathrm{Am}, \mathrm{Cm})$ at Time of Reprocessing 


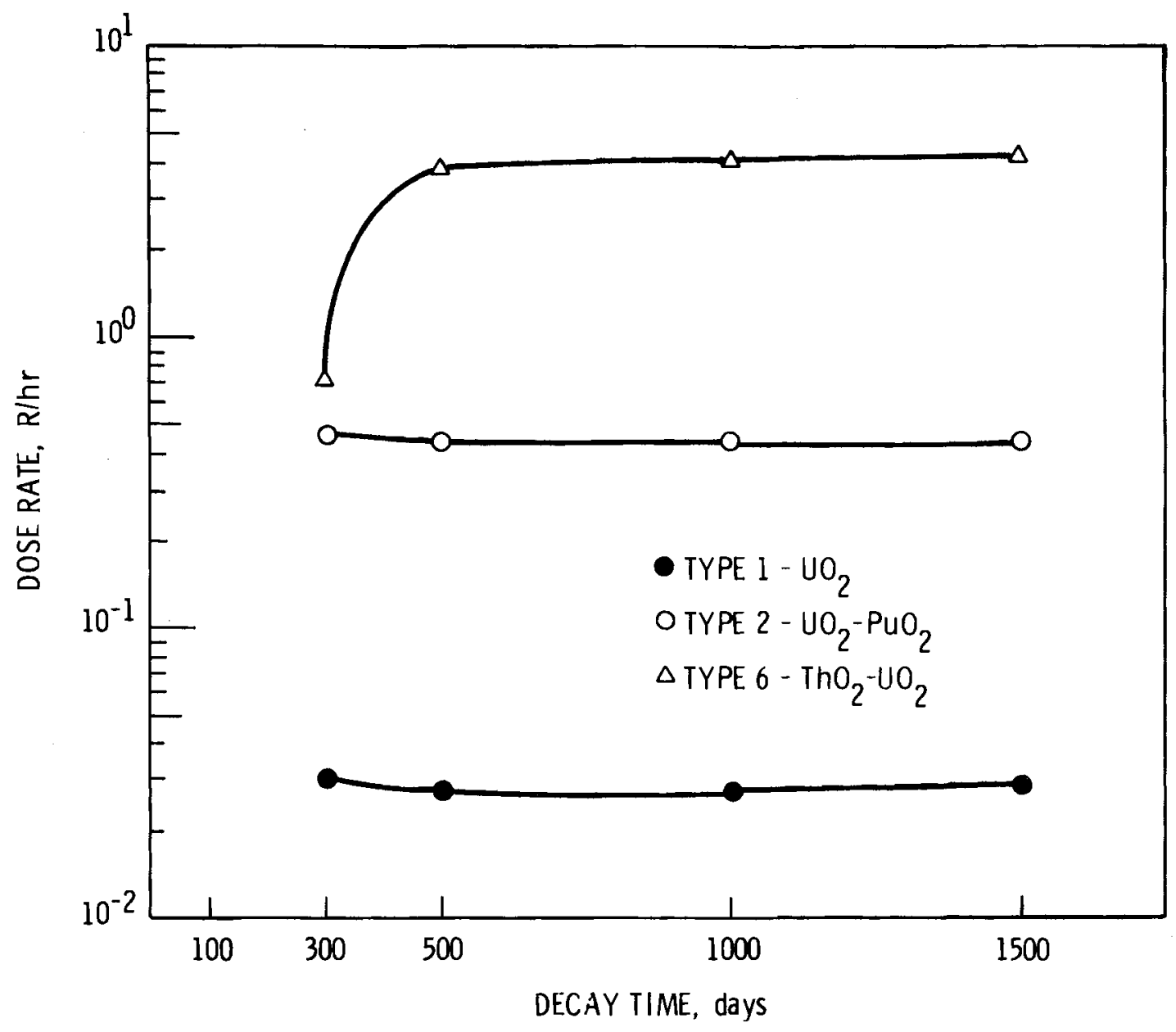

FIGURE 19. Dose Rates at One Meter from $10 \mathrm{~kg}$ Sphere of Recovered Fuel after Full Burnup with Complete Separation of Fission Products at Time of Reprocessing 


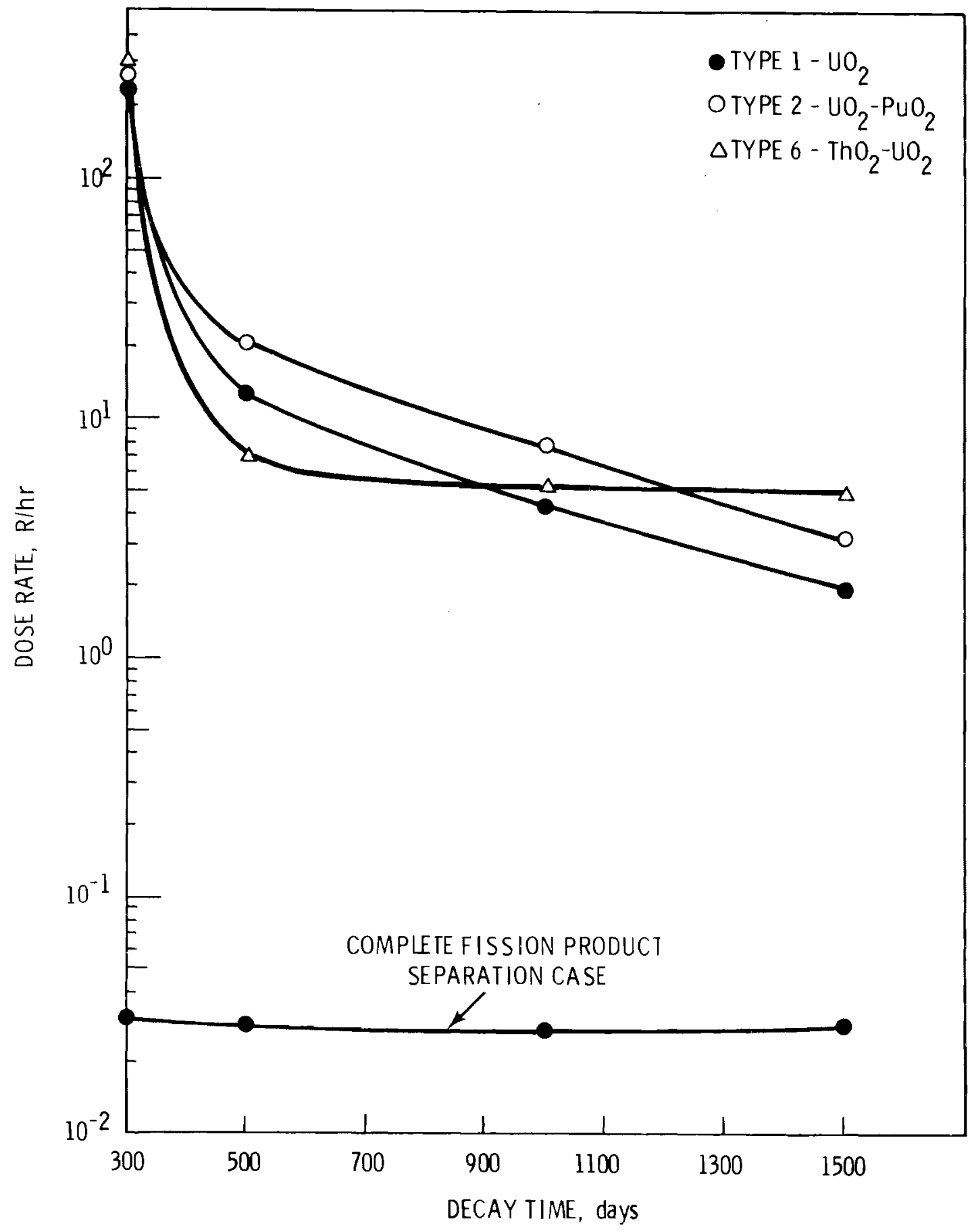

FIGURE 20. Dose Rates at One Meter from $10 \mathrm{~kg}$ Sphere of Fu11 Burnup Fuel, with CIVEX Separation of Fission Products 


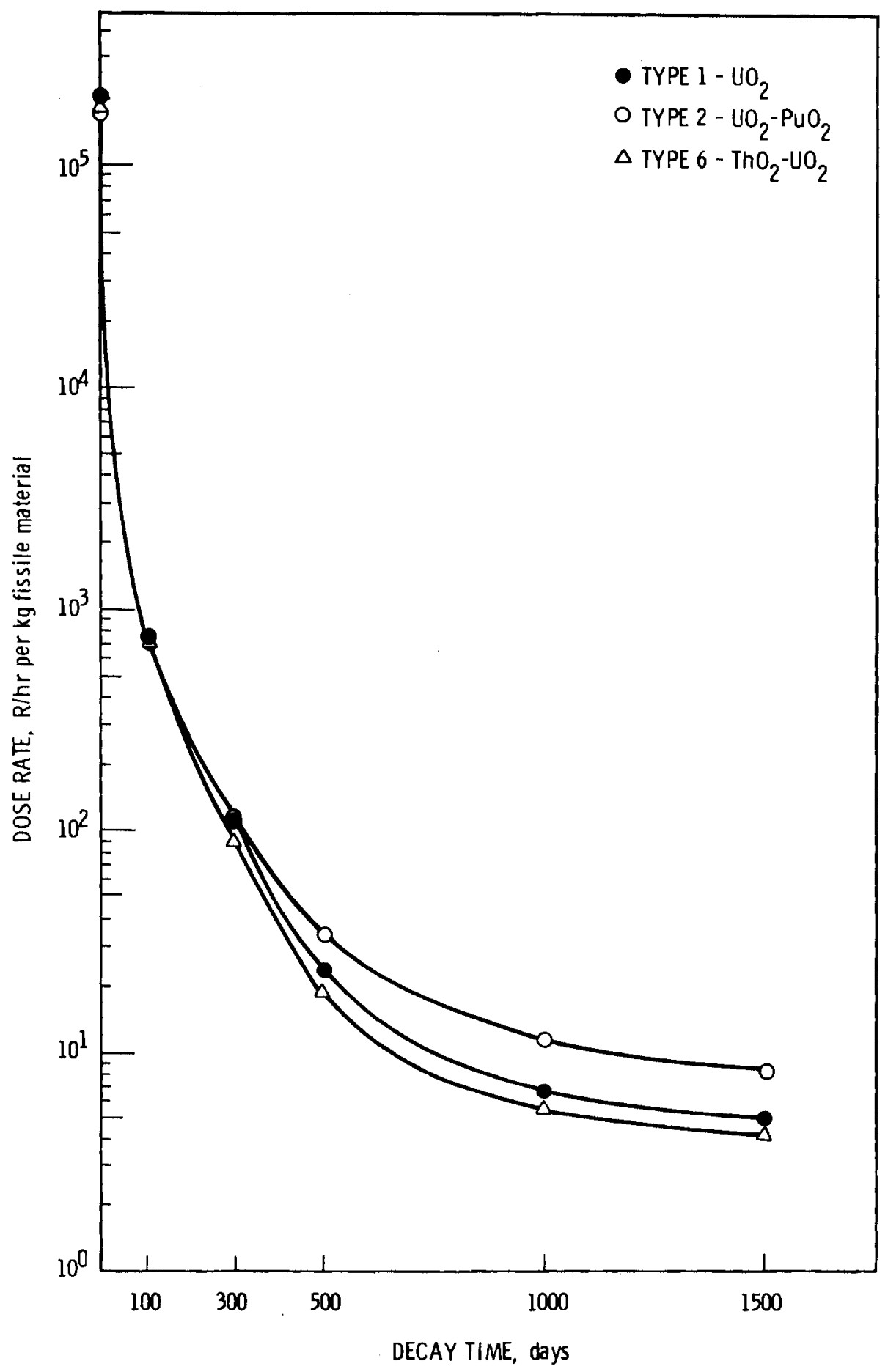

FIGURE 21. Dose Rates per kg Fissile Material at One Meter from $10 \mathrm{~kg}$ Sphere of 1\% Burnup Pre-Irradiated Fuel 


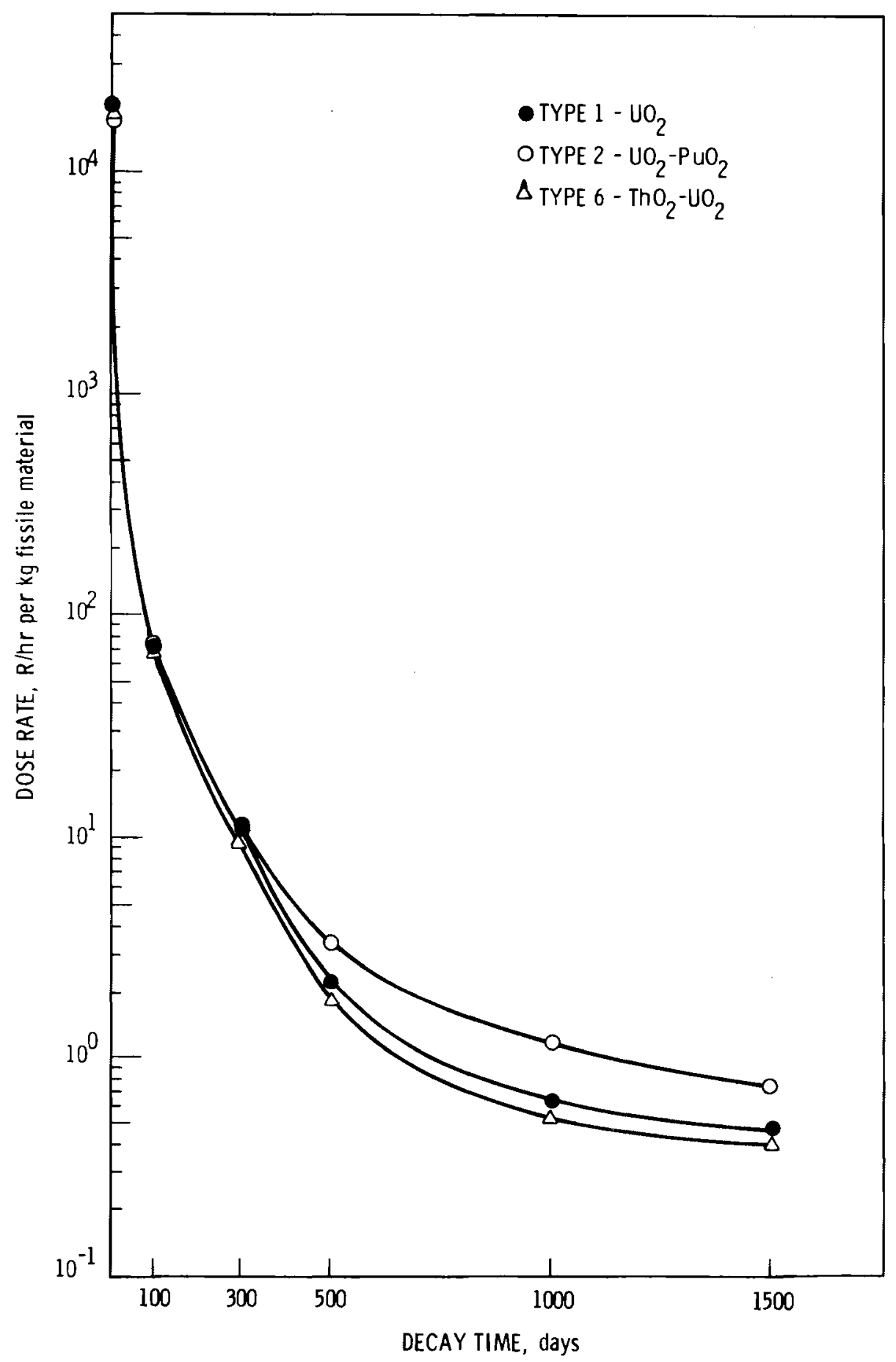

FIGURE 22. Dose Rates per kg Fissile Material at One Meter from $10 \mathrm{~kg}$ Sphere of $0.1 \%$ Burnup Pre-Irradiated Fuel 


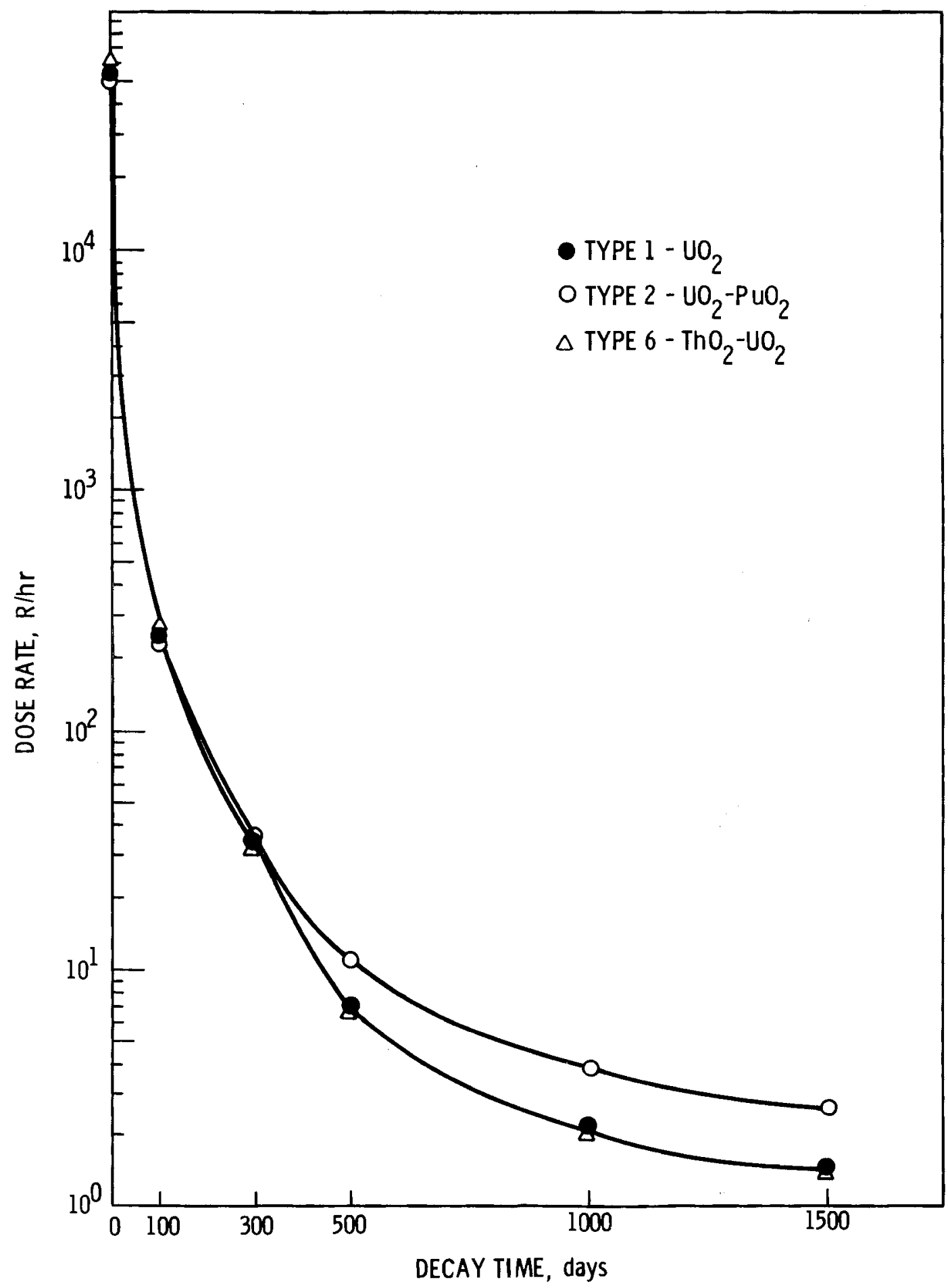

FIGURE 23. Dose Rates at One Meter from $10 \mathrm{~kg}$ Sphere of 1\% Burnup Pre-Irradiated Fuel 


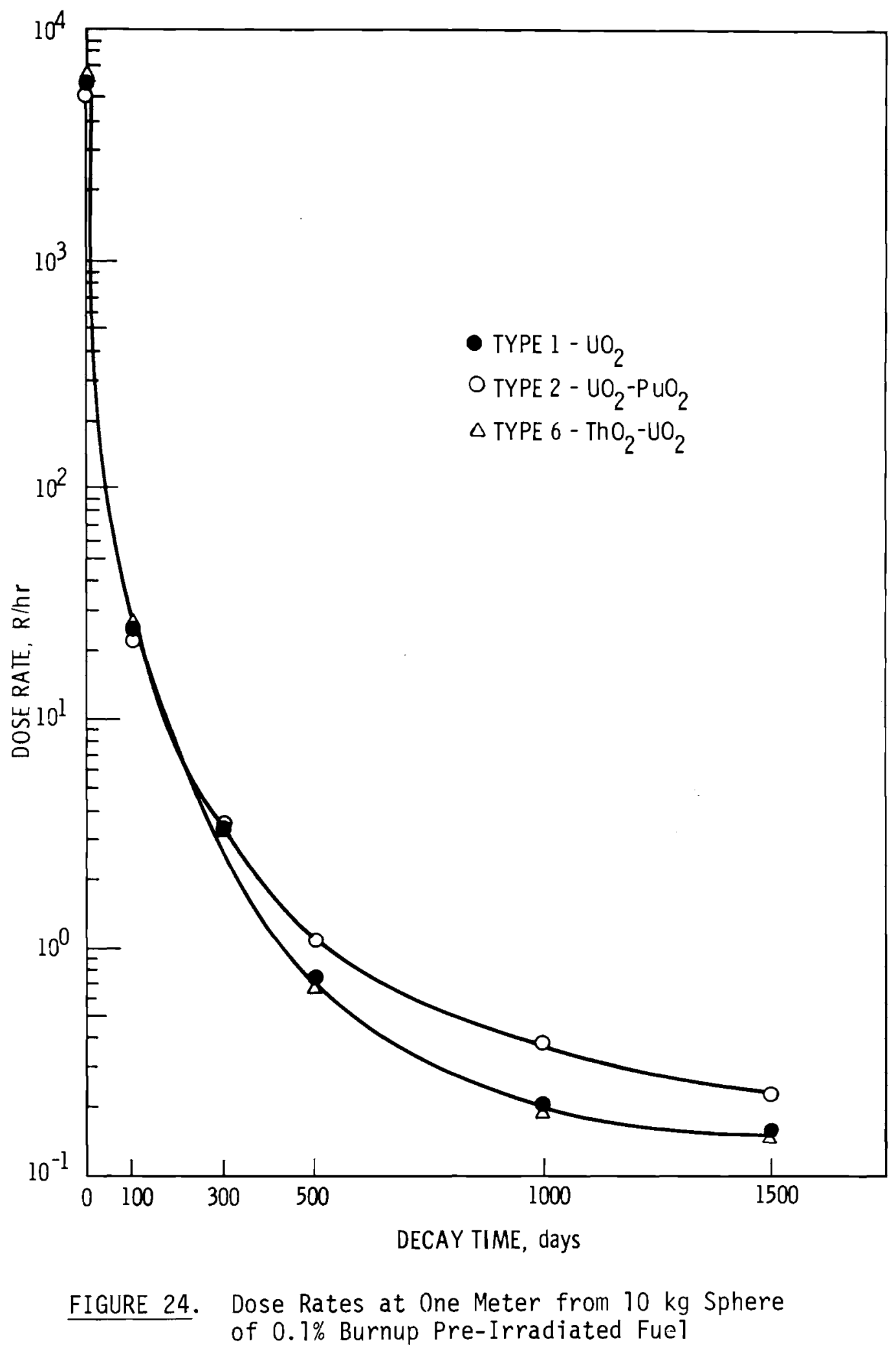




\section{REFERENCES}

1. The Energy Daily, July 25, 1978 Volume 6, Number 142.

2. E.T. Merri11, "ALTHAEA: A One-Dimensional Two-Group Diffusion Code with an Effective Four-Group Burnup," BNWL-462, Pacific Northwest Laboratory (May 1971).

3. T.M. Helm, et a1., "Reactor Design Characteristics and Fuel Inventory Data," Volume I (Pressurized Water Reactors) contributed by Combustion Engineering, Inc., Compiled and Edited by HEDL (Sept. 1977).

4. Deleted.

5. M.J. Be11, "ORIGEN: The ORNL Isotope Generation and Depletion Code," ORNL-4628, Oak Ridge National Laboratory (May 1973).

6. W.W. Engle, Jr., "A Users Manual for ANISN: A One-Dimentional Discrete Ordinates Transport Code with Anisotropic Scattering," K-1693 Union Carbide Corp., Oak Ridge Gaseous Diffusion Plan (March 1967).

7. Paul R. Kasten, H.C. Carney, "Proliferation Analysis of Thorium Fuel Cycles in Thermal Reactors" (Draft) Oak Ridge National Laboratory (June 1978).

8. R.V. Laney, P.R. Huebotter (ANL), "Nonproliferation Criteria for Nuclear Fuel Cycles," Trans. Am. Nucl. Soc., 28, 320 (1978).

9. A.de 1a Garza, "Uranium-236 in Light Water Reactor Spent Fuel Recycled an Enriching Plant," Nuclear Technology, Vol. 32, February 1977.

10. M. Levenson and E. Zebroski, "A Fast Breeder System Concept: A Diversion Resistant Fuel Cycle" presented at the 5th Energy Technology Conference, Washington, D.C. (February 27, 1978).

11. "Spiking Recycled LWR Fuel," Savannah River Laboratory Monthly Report, DP-78-1-2, (February 1978). 


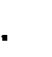

. 
APPENDIX A

DESCRIPTION OF THE NUCLEAR FUEL CYCLE 
The key elements to the nuclear fuel cycle are:
A. Fuel Production
B. Fuel Utilization
C. Fuel Recovery

Several operations comprise each of the above key elements and a brief explanation of each of these operations follows.

\section{A. Fuel Production}

1. Mining

Most of the domestic uranium ore is found in Colorado, Wyoming, New Mexico, and Utah. This ore typically has an average assay of $0.2 \% \mathrm{U}_{3} \mathrm{O}_{8}$. Predominantly, there are two methods of uranium mining in the U.S.,

1) Underground Mining

2) Open-pit Mining

The solid waste associated with underground mining will approximate the volume of processed ore. In open-pit mining, the stripping ratio (volume of overburden to volume of ore) will average 30-1.

\section{Milling}

Located contiguous to the mining operation is the milling facility. Here, the process of extracting uranium from the mined ore is accomplished. Chemical and mechanical methods are used to produce a semi-refined product which contains $70-90 \% \mathrm{U}_{3} \mathrm{O}_{8}$, commonly referred to as "yellow cake." The primary process used for the milling of most domestic ore is the acid-leach process. The basic steps to this process are:

1) The ore is crushed then wet ground in a rod or ball mill and transferred as a slurry to leaching tanks.

2) Sulphuric acid and an oxidizing reagent are added to leach the uranium from the ore. The tailings are then washed and the product is pumped to solvent-extraction units.

3) The uranium is purified and concentrated in the solvent extraction step.

4) The uranium is then precipitated with ammonia and transferred as a slurry.

5) The concentrate is centrifuged to thicken and separate it from residual liquids. 
6) The concentrate is calcined and subsequently pulverized.

7) The powdered "yellow cake" is then packaged in 55 gallon drums for shipment to the conversion process.

\section{Conversion}

The $\mathrm{U}_{3} \mathrm{O}_{8}$ concentrate ("yellow cake") must then be converted to the volitile compound uranium hexafluoride $\left(U F_{6}\right)$ for enrichment by the gaseous diffusion process. In the conversion step, all of the remaining impurities are removed from the $\mathrm{U}_{3} \mathrm{O}_{8}$ concentrate and a highly purified uranium hexafluoride product remains.

There are two different processes for uranium hexafluoride production. The "dry hydrofluor process" and the "wet solvent extraction process." The "dry hydrofluor process" consists of the following steps:

1) Fluidized-bed reduction of the $\mathrm{U}_{3} \mathrm{O}_{8}$ to $\mathrm{UO}_{2}$ with cracked ammonia.

2) Fluidized-bed hydrofluorination with anhydrous $\mathrm{HF}$ to form a crude $\mathrm{UF}_{4}$.

3) Fluidized-bed fluorination with elemental fluorine to form crude $U_{6}$.

4) Fractional distillation for form refined $U F_{6}$.

The wet extraction method consists of the following operations:

1) Digestion in hot nitric acid.

2) Counter current solvent extraction with tributylphosphate (TBP) in hexane.

3) Stripping of uranium as uranyl nitrate into an aqueous solution.

4) Calcining to $\mathrm{NO}_{3}$.

5) Fluidized-bed reduction to $\mathrm{UO}_{2}$ with cracked ammonia.

6) Hydrofluorination in a two stage counter current reactor to $\mathrm{UO}_{4}$ using anhydrous HF.

7) Fluorination to $U_{6}$ by reaction with elemental fluorine.

Each of these methods produce essentially equal quantities of $U F_{6}$ feed for the enrichment plants.

\section{Enrichment}

The concentration of $235 \mathrm{U}$ in natural uranium is $0.711 \%$. To supply fuel to the LWR industry at $2-4 \% 235 \mathrm{U}$, isotopic enrichment is necessary. The $U_{6}$ prepared by the conversion step is used in the isotopic enrichment process to increase the concentration of fissile $235 \mathrm{U}$ in natural uranium. The method currently being used by the U.S. for isotopic $235 \mathrm{U}$ enrichment of natural uranium is the gaseous diffusion process. 
The gaseous diffusion process is based on the principle that the rate at which a gas diffuses through a porous barrier is a function of the speed and therefore of the masses of the gas molecules. The barriers used in the uranium separation process contain hundreds of millions of pores per square inch. The lighter isotopic molecule will diffuse through such a barrier faster than a heavier molecule, so that a partial separation of the isotopes results. The gas which diffuses through the barrier first will be slightly richer in the lighter isotope $235 \mathrm{U}$.

An enrichment plant consists of an array of "stages" connected in series, with each stage being the smallest unit of separation equipment. The barrier material is contained in each stage. Each individual stage takes a feed stream and divides it into two streams, one being slightly enriched in the lighter isotope $235 \mathrm{U}$, the other being slightly depleted relative to $235 \mathrm{U}$.

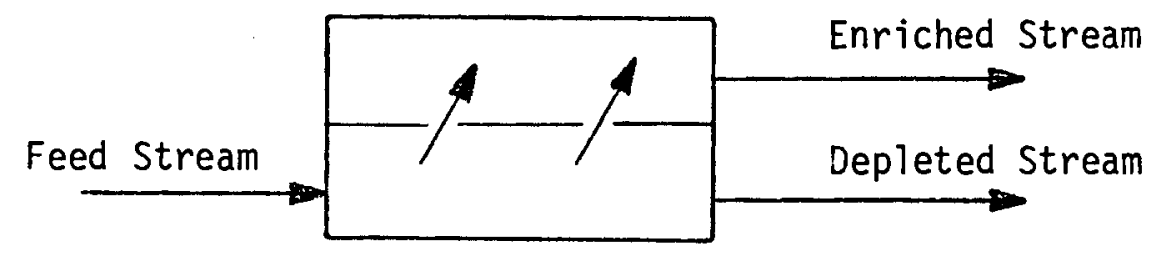

The extent of separation of isotopes for each stage can be expressed by means of a separation factor. It is defined as the ratio of $235 \mathrm{U}$ to 238 atoms in the enriched state to that in the residual state and is inversely proportional to the square root of the molecular weights of the heavier and lighter isotopic diffusion species.

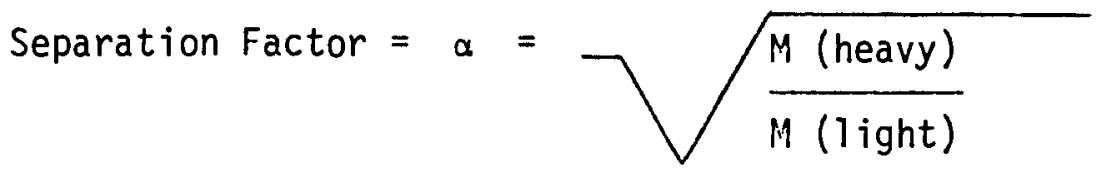

For UF $F_{6}$ the value of this factor is 1.0043. Since it is so close to unity, the degree of enrichment in any stage is very small. By combining several stages in series to form a "cascade", this effect can be multiplied until the enriched stream contains the desired amount of $235 \mathrm{U}$.

The work required for each stage to perform the required separation is described in terms of "units of separation work." A separative work unit (SWU) is a measure, expressed in mass units, of the effort expended to separate a quantity of uranium of a given assay into two components, one having a higher percentage of the $235 \mathrm{U}$ isotope, the other (tails) having a lower percentage of $235 \mathrm{U}$. 


\section{Fuel Fabrication}

Enriched $U F_{6}$ from the gaseous diffusion plant is received in sealed 2.5 ton cylinders, converted to $\mathrm{UO}_{2}$, and fabricated into fuel assemblies. The process steps involved in converting the $\mathrm{UF}_{6}$ to $\mathrm{UO}_{2}$ are based on the ammonium diurinate (ADU) process. These steps are as follows:

1) $U F_{6}$ is heated and transferred as a gas to a tank for hydrolysis.

2) Hydrolysis results from the interaction of the gaseous $U_{6}$ with water forming a $\mathrm{UO}_{2} \mathrm{~F}_{2}$ solution.

3) Precipitation of ADU is done by adding ammonium hydroxide.

4) The ADU slurries are then concentrated and dried by heating.

5) The dried $A D U$ is calcined to $\mathrm{UO}_{2}$ powder in a reducing atomsphere.

The dried $\mathrm{UO}_{2}$ powder is then mechanically treated prior to fabrication. The steps for this treatment are:

1) Pre-treatment of $\mathrm{UO}_{2}$ powder by comminution, compaction and granulation to desired size distribution.

2) Pelletizing.

3) Sintering.

4) Grinding to finished dimensions.

5) Washing and cleaning the pellets.

6) Loading the pellets into metal tubes and welding the end caps.

7) Assembling the fuel rods into finished fuel assemblies ready for loading into a reactor core.

\section{B. Fuel Utilization}

\section{Irradiation}

At the reactor, fresh fuel assemblies are loaded into the core and optimally burned for a pre-determined period of time, expressed in units of MWd/MTU. This represents the total amount of energy extracted from the fuel. On the average, a PWR or BWR will make one refueling per year. Typically this involves replacing about 1/3 of a PWR core and about 1/4 of BWR core. Upon removal from the core, an assembly will be stored outside the core region for approximately 10 days, then placed in the spent fuel storage basin for a minimum of 120-180 days before shipping. The purpose for storing these elements is that they are intensely radioactive and very hot thermally. After irradiation at 25,000 MWd/MTHM, a spent fuel assembly will have a thermal power of $640 \mathrm{KW}$ and will have a betagamma dose-rate in excess of $10^{6} \mathrm{R} / \mathrm{hr}$. 


\section{Fuel Recovery}

\section{Fuel Reprocessing}

Fuel elements discharged from the reactor contain about $1 / 3$ of the $235 \mathrm{U}$ that was in the fuel prior to irradiation and plutonium that was produced by the irradiation and plutonium that was produced by the irradiation of $238 \mathrm{U}$. If a thorium based fuel is discharged, it will contain fissile $233 \mathrm{U}$. The recovery and subsequent recycling of these fissile materials is the purpose of fuel reprocessing.

The sequence of events consists primarily of the head-end process, dissolution, solvent extraction and purification and conversion.

\section{Head-End Process}

Once received, spent fuel is transferred to a holding basin and stored for a period of time which is dependent on its age and the throughput of the plant. It is then mechanically sheared into pieces which are approximately 1 inch in length. As this is done, some of the noble gases such as krypton and xenon, as well as the volitile fission products are released and vented to the dissolver off-gas system. The sheared fuel pieces are collected in a basket-like device and transferred to the dissolver.

\section{Dissolution}

Hot nitric acid is then added to dissolve the sheared fuel assemblies. As this is done the remaining noble gases present as well as some ruthenium, tritium, iodine and carbon-14 are released and vented to the dissolver offgas system. The dissolver solution is centrifuged to remove any suspended solids and sludges prior to the solvent extraction step. The fuel cladding hulls are collected, rinsed and stored for treatment.

\section{Solvent Extraction}

Plutonium and uranium are separated from the fission products during the solvent extraction process. The uranium and plutonium are extracted into the organic stream with a 30\% TBP-70\% dodecane fraction, while the aqueous stream contains the fission products. The organic phase $U+P u$ stream is then subjected to additional solvent extraction cycles to separate the uranium from the plutonium. (If a CO-MOX or CIVEX process is used, the $U+P u$ would remain in the same stream and would be stripped to the aqueous phase before purificationconversion.) The $\mathrm{Pu}$ product will be in the aqueous phase after stripping and will subsequently be sent to the Pu purification-conversion step, while the 
uranium product will be in the organic phase and must be stripped to the aqueous phase before purification and conversion.

\section{Purification and Conversion}

Any remaining impurities such as fission products are stripped from the uranium and plutonium streams at this point. The uranium is then converted to $\mathrm{UF}_{6}$ as described earlier while the $\mathrm{Pu}$ is converted to $\mathrm{PuO}_{2}$ in a calciner. Both products are then sent to a Fuels Refabrication Facility prior to core insertion.

\section{Refabrication}

Following the purification and conversion step of reprocessing, either fissile uranium and/or plutonium will be sent to a Fuel Refabrication Facility. Here, the fissile material will be blended with fertile material such as natural uranium or thorium and refabricated into recycle fuel. This facility is very similar to the fabrication plant discussed earlier with one major exception, it must be remotely operated facility if thorium is recycled and/or radioactive fission products are used as spikants in the plutonium systems.

Inherent to thorium recycle is the presence of ${ }^{208} \mathrm{Tl}$ in the $232 \mathrm{U}$ decay chain. This element decays with the emission of a $2.6 \mathrm{MeV}$ gamma. Its presence in the fuel material prohibits direct handling during refabrication. Typically, $232 \mathrm{U}$ will constitute 500-1000 ppm of the fuel material in the steady-state condition. Figure 16 shows the approximate dose-rate at one foot for fuel material containing that concentration. 
APPENDIX B

NORMALIZATION OF NUCLEAR FUEL BURNUP MODEL 


\section{APPENDIX B \\ Normalization of Nuclear Fuel Burnup Model}

The computer code ALTHAEA was chosen to perform the burnup calculations for this study because of its computing speed, accuracy and flexibility (2). A zerodimensional burnup calculation is used to generate all of the discharge isotopics. The saturating neutron poisons, xenon and samarium are assumed to be in equilibrium. To account for changing isotopic concentrations with burnup and spectrum variations, the code recalculates the macroscopic cross-sections at each burnup step assuming that the power remains constant during each burnup step.

For consistency with reference alternative fuel isotopic compositions and reactivity requirements, the use of ALTHAEA for this analysis necessitated the calibration of the code to match the discharge isotopic compositions computed by Combustion Engineering ${ }^{(3)}$. These compositions were calculated for each of the seven basic fuel types used in this analysis. Specific modifications were made to ALTHAEA for each fuel type such that the isotopics at goal exposure predicted by ALTHAEA were in reasonable agreement with the steady state discharge isotopics calculated by Combustion Engineering. Thus, there were seven specific, independent sets of modifications. All burnup calculations for a given fuel type were made using a single set of modifications relative to that fuel type. An exception to this occurred in two instances, 1) when the successive elimination of thoria from the denatured urania-thoria fuel reached a point where the thoria was less than $50 \%$ of the total fuel material, and 2) when the predominant fissile material in the $\mathrm{UO}_{2}-\mathrm{PuO}_{2}$ fuel type was $235 \mathrm{U}$. In these instances, the LEU set of modifications to ALTHAEA were used along with the appropriate changes to account for the thorium and $233 \mathrm{U}$ when present.

The modifications to ALTHAEA included the following:

1) Changes in the energies per fission for all fissile isotopes.

2) Changes in the fission and absorption cross-sections of selected isotopes which were made by adjusting the respective $2200 \mathrm{~m} / \mathrm{sec}$ values and the resonance integrals.

3) Changes in the effective height of the NRIA resonance.

4) Spectrum changes were made by adjusting the individual neutron group flux levels relative to one another. This was done with the RAYK constants;

RAYKI - Group 2 relative to 4

RAYK2 - Group 3 relative to 2 


$$
\begin{aligned}
& \text { RAYK3 - Group } 4 \text { (adjusts effective neutron temperature in the thermal } \\
& \text { region. } \\
& \text { GSHLD - Group } 4 \text { (adjusts the assumed } 1 / v \text { cross-sections of isotopes with } \\
& \text { near thermal resonances to account for reactions with neutrons in } \\
& \text { the upper energy portion of the Maxwellian. }
\end{aligned}
$$

The neutron group energy cutoffs are as follows;

$$
\begin{aligned}
& >200 \mathrm{kev} \text { Group } 1 \\
& .685 \text { - } 200 \mathrm{kev} \text { Group } 2 \\
& .685 \text { - } 3.68 \text { KT Group } 3 \\
& \text { where } K=\text { Boltzman's Constant } \\
& \text { where } T=\text { Temperature }\left(K^{\circ}\right) \\
& \text { Maxwellian Group } 4
\end{aligned}
$$


TABLE B-1

Specific Fuel Type Modifications For ALTHAEA

$$
\mathrm{ThO}_{2}-\mathrm{PuO}_{2}
$$

Change 204.5

205

205

7.6

1.8

1.85

3340

$4.38 \times 10^{5}$

978

1350

RAYKI $=.55$
Description

MeV/Fission $233 \mathrm{U}$

MeV/Fission $239 \mathrm{Pu}$

MeV/Fission $241 \mathrm{Pu}$

2200 Meter Sigma Absorption ${ }^{232} \mathrm{Th}$

Fission Resonance Integral ilultiplier $233 \mathrm{U}$

Absorption Resonance Integral Multiplier ${ }^{233} \mathrm{U}$

Effective Height of NRIA Resonance $232 \mathrm{Th}$

Effective Height of NRIA Resonance $240 \mathrm{Pu}$

2200 Meter Signma Absorption $239 \mathrm{Pu}$

2200 Meter Sigma Absorption $241 \mathrm{Pu}$

RAYK2 $=.4$

RAYK3 $=.61973$

$\mathrm{ThO}_{2}-(20 \% 235 \mathrm{U}) \mathrm{UO}_{2}$ 01d Value

198.

208

210

7.4

1.297

1.434

8200

$1.69 \times 10^{5}$

1008.1

1336

GShld $=.25$
Change

204.5

202.5

205

205

205

1.93

3600

7.6

11.3

500

780

34500

RAYKI $=.725$
Description

MeV/Fission ${ }^{233} \mathrm{U}$

$\mathrm{MeV} / \mathrm{Fission} 235 \mathrm{U}$

MeV/Fission 239Pu

$\mathrm{MeV} / \mathrm{Fission} 241 \mathrm{Pu}$

Absorption Resonance Integral Multiplier $233 \mathrm{U}$

Fission Resonance Integral Multiplier $233 \mathrm{U}$

Effective Height of NRIA Resonance ${ }^{232} \mathrm{Th}$

2200 Meter Sigma Absorption $232 \mathrm{Th}$

Absorption Resonance Integral Multiplier $232 \mathrm{Th}$

2200 Meter Sigma Fission $239 \mathrm{Pu}$

2200 Meter Sigma Fission ${ }^{239} \mathrm{Pu}$

Effective Height of NRIA Resonance $238 \mathrm{U}$

RAYK2 $=.01$
RAYK3 $=.61973$ old value

198

200

208

210

1.434

1.297

8200

7.4

11.069

754

1008.1

20400

GShld $=.3$ 
Change

204.5

202.5

1.44

504

810

4800

7.6

40000

$1.8 \times 10^{5}$

RAYK1 $=.585$

Change

1313

.55

$3.15 \times 10^{5}$

202.5

205

205

RAYK1 $=.63$
Description

MeV/Fission $233 \mathrm{U}$

$\mathrm{MeV} / \mathrm{Fission} 235 \mathrm{U}$

Absorption Resonance Integral Multiplier $233 \mathrm{U}$

2200 Meter Sigma Fission 239pu

2200 Meter Sigma Absorption $239 \mathrm{pu}$

Effective Height of NRIA Resonance ${ }^{232} \mathrm{Th}$

2200 Meter Sigma Absorption ${ }^{232} \mathrm{Th}$

Effective Height of NRIA Resonance ${ }^{238} \mathrm{U}$

Effective Height of NRIA Resonance $240 \mathrm{Pu}$

RAYK2 $=.25$

RAYK3 $=.61973$

$\mathrm{UO}_{2}-\mathrm{PuO}_{2}$

Description

2200 Meter Sigma Absorption $241 \mathrm{Pu}$

Fraction of Epithermal Resonance Integral

Not subject to Cross Shielding $235 \mathrm{U}$

Effective Height of NRIA Resonance $240 \mathrm{Pu}$

MeV/Fission $235 \mathrm{U}$

MeV/Fission $239 \mathrm{Pu}$

MeV/Fission $241 \mathrm{Pu}$

RAYK2 $=.7$

RAYK3 $=.61973$ old value

198

200

1.434

754

1008.1

8200

7.4

20400

$1.696 \times 10^{5}$

GShld $=.15$

old Value

1336

.75

$1.696 \times 10^{5}$

200

208

210

GShld $=.4$

Change

$(<4 \% 235 \mathrm{U}) \mathrm{UO}_{2}$

Description

old Value

202.5

MeV/Fission $235 \mathrm{U}$

200

RAYK1 $=.675$

RAYK2 $=.25$

RAYK3 $=.619$

GShTd $=.15$ 


$$
\begin{aligned}
& \text { TABLE B-1 (con't) } \\
& \mathrm{ThO}_{2}-(93 \% 235 \mathrm{U}) \mathrm{UO}_{2}
\end{aligned}
$$

Change

204.5

202.5

1.12

1.32

6000

7.6

RAYK1 $=.55$

Change

202.5

204.5

1.44

7.6

4800
Description

MeV/Fission $233 \mathrm{U}$

$\mathrm{MeV} /$ Fission $235 \mathrm{U}$

Fission Resonance Integral Multiplier ${ }^{233} \mathrm{U}$

Absorption Resonance Integral Multiplier $233 \mathrm{U}$

Effective Height of NRIA Resonance ${ }^{232} \mathrm{Th}$

2200 Meter Sigma Absorption 232Th

RAYK2 $=.25$

RAYK3 $=.61973$

$(<3 \% 233 \mathrm{U}) \mathrm{UO}_{2}$

Description

MeV/Fission 235U

MeV/Fission $233 \mathrm{U}$

Absorption Resonance Integral Multiplier $233 \mathrm{U}$

2200 Meter Sigma Absorption ${ }^{232} \mathrm{Th}$

old Value

198

200

1.297

1.434

8200

7.4

GShld $=.15$

01d Value

200

198

1.434

7.4

8200 
.

, 
APPENDIX C

DETAILED DESCRIPTION OF

ALTERNATIVE FUEL CYCLE MASS FLOW RATES 


\section{APPENDIX C \\ DETAILED DESCRIPTION OF ALTERNATIVE FUEL CYCLE MASS FLOW RATES}

Figures $\mathrm{C}-1$ through $\mathrm{C}-7$ identify in detail the seven basic alternative fuel cycles. Each segment of each fuel type chain is identified as well as its basic composition. Figures 1 through 7 were derived from these detailed mass flow rates. Table $C-1$, lists the neutron multiplication factor $k_{\infty}$ at $2 / 3$ goal exposure used for each fuel type. 
TABLE C-1

NEUTRON MULTIPLICATION CONSTANTS

AT TWO-THIRDS GOAL EXPOSURE

- Fuel Type

LEU

$\mathrm{Pu}-\mathrm{U}$

Pu-Th

HEU-Th

Du-Th

Du-Th

HEU-Th
Fuel Composition

$$
(<4 \% 235 \mathrm{U}) \mathrm{UO}_{2}
$$

$\mathrm{UO}_{2}-\mathrm{PuO}_{2}$

$\mathrm{ThO}_{2}-\mathrm{PuO}_{2}$

$\mathrm{ThO}_{2}-23 \mathrm{UO}_{2}$

$\mathrm{ThO}_{2}-\left(20 \%{ }^{235} \mathrm{U}\right) \mathrm{UO}_{2}$

$\mathrm{ThO}_{2}-\left(<11 \%{ }^{235} \mathrm{U}\right) \mathrm{UO}_{2}$

$\mathrm{ThO}_{2}-(93 \% 235 \mathrm{U}) \mathrm{UO}_{2}$

$\frac{k_{\infty}}{1.035}$
1.032
1.054
1.007
1.033
1.007
1.025



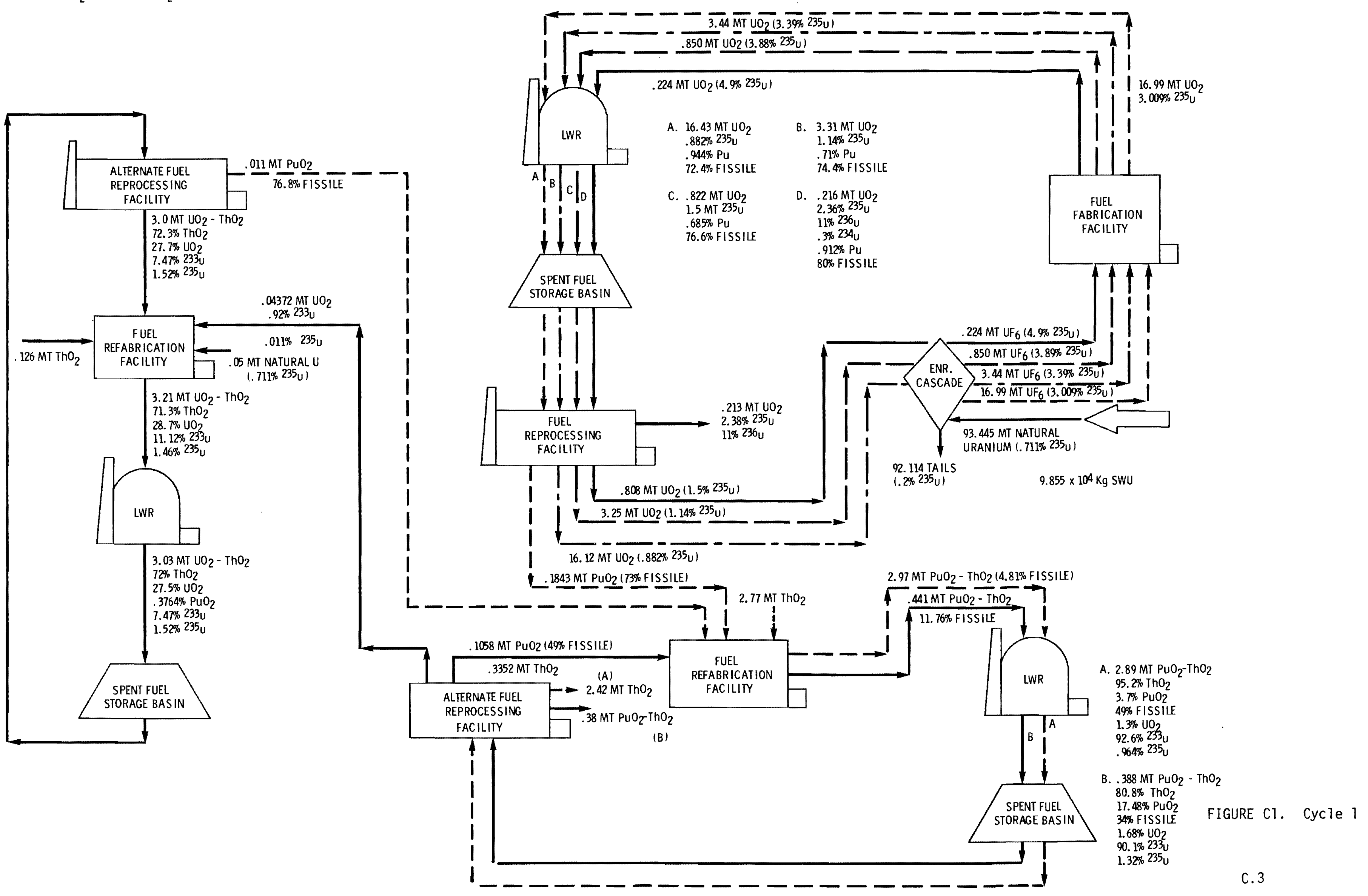

CYCLE 2- FUEL CYCLE CONSTITUENTS

LEU ( $\angle \%$ 235U) UO 2 (PRIMARY)

Pu-Th $\mathrm{ThO}_{2}-\mathrm{PuO}_{2}$ (SECONDARY)

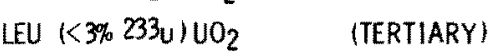

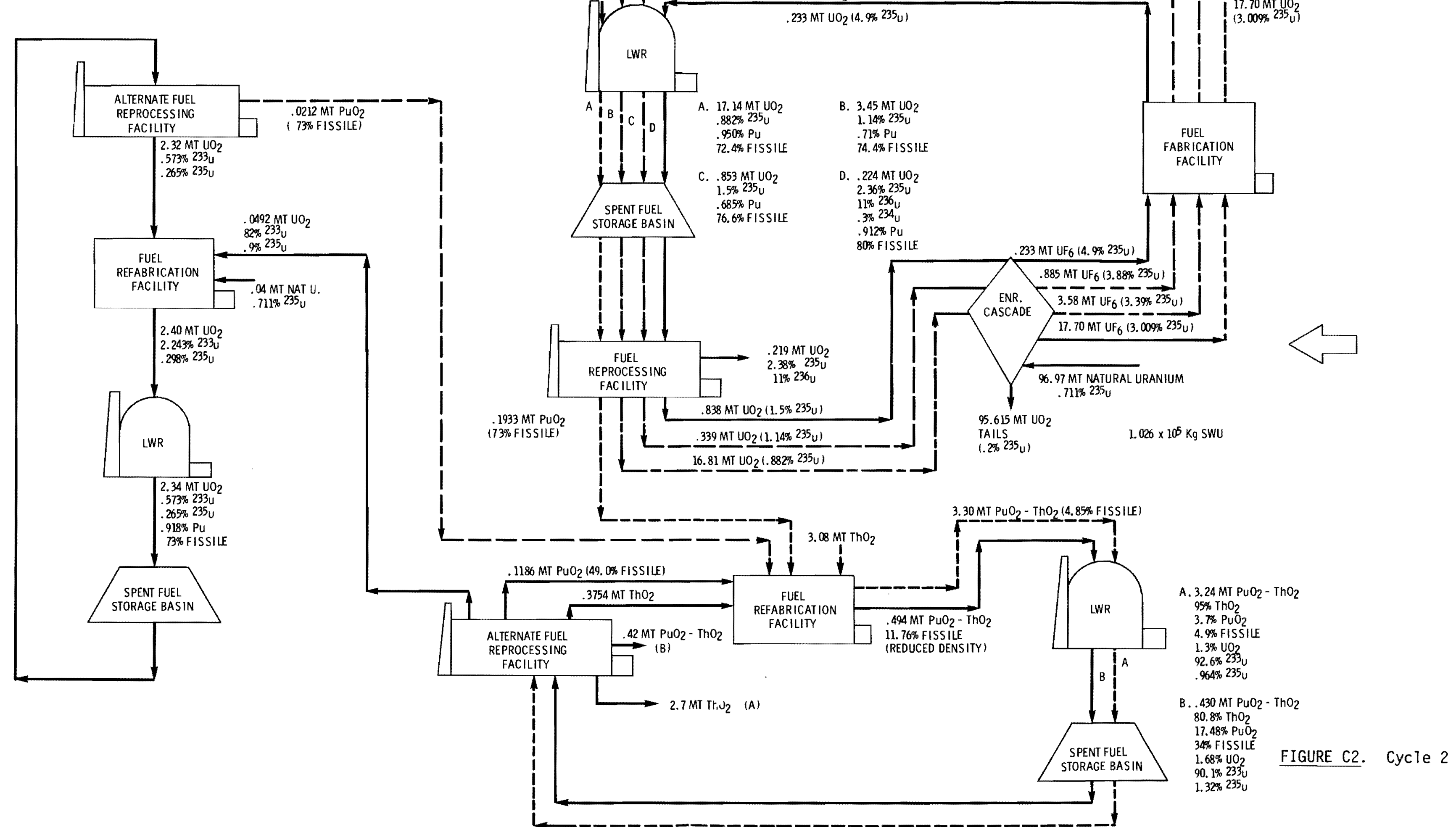


FIGURE C-3:

CYCLE 3-FUEL CYCLE CONSTITUENTS

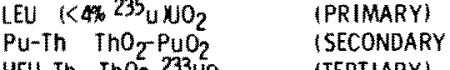

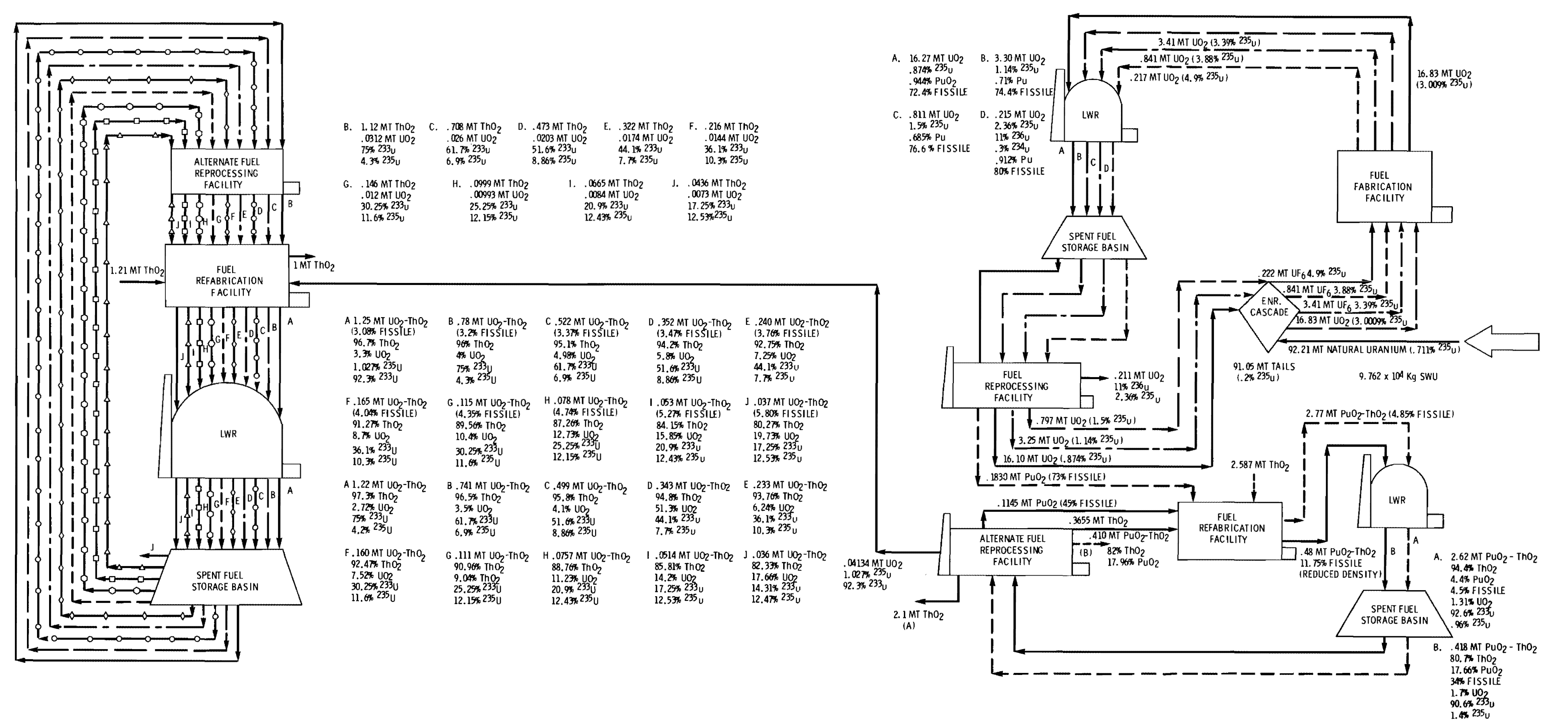

FIGURE C3. Cycle 3 



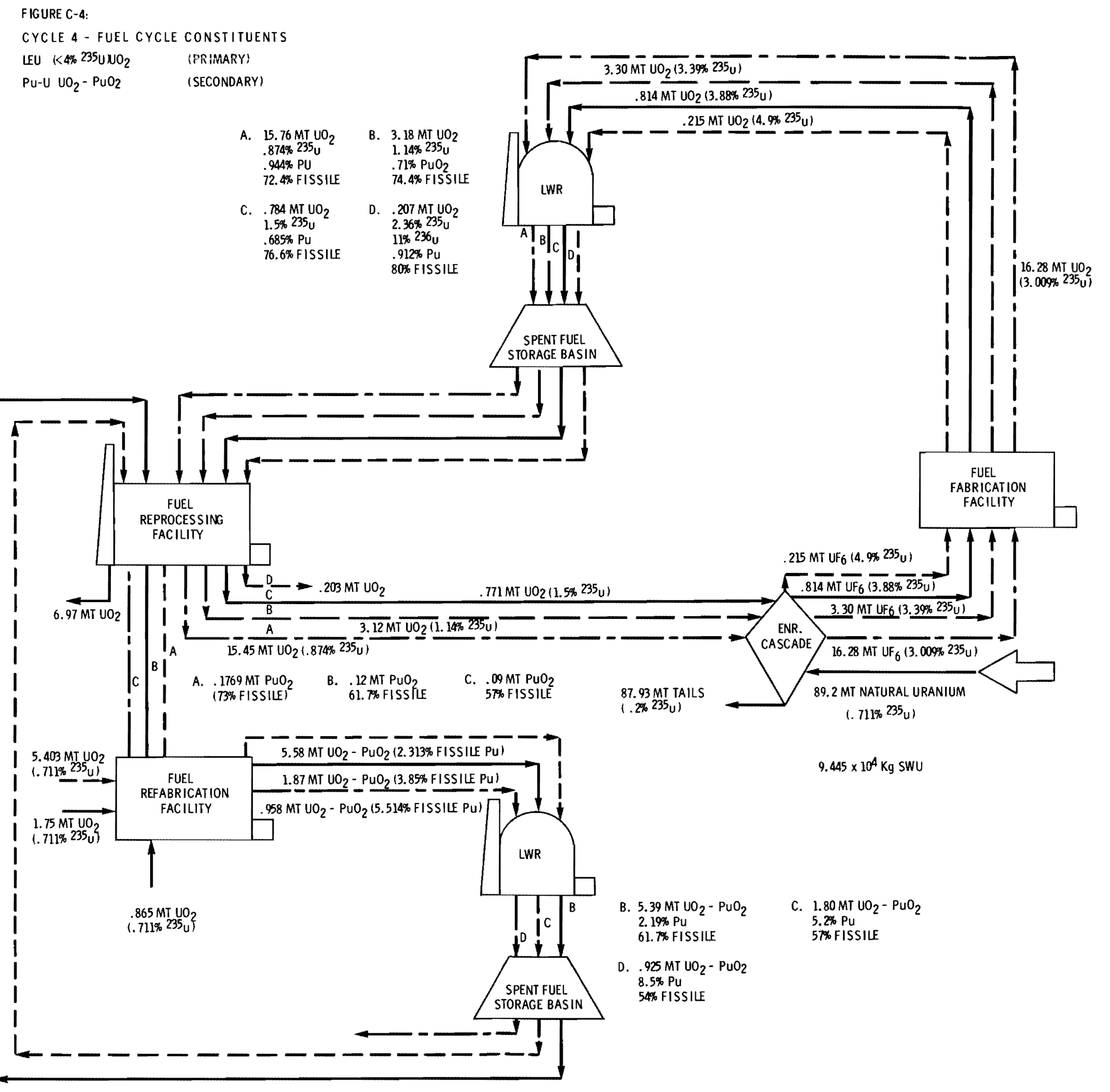

FIGURE C4. Cycle 4 

FIGURE C-5

CYCLE 5 - FUEL CYCLE CONSTITUENTS

OU-Th $\mathrm{ThO}_{2}-\left(20 \% 6 \mathrm{O}_{2} \mathrm{UO}_{2}\right.$ (PRIMARY

DU-Th ThO $\mathrm{T}_{2}-\mathrm{KLIF}^{2}{ }^{233} \mathrm{UI} \mathrm{UO}_{2}$ (ISECONDARY

$\mathrm{Pu}-\mathrm{U} \quad \mathrm{UO}_{2}-\mathrm{PuO}_{2}$

(ERTIARY)
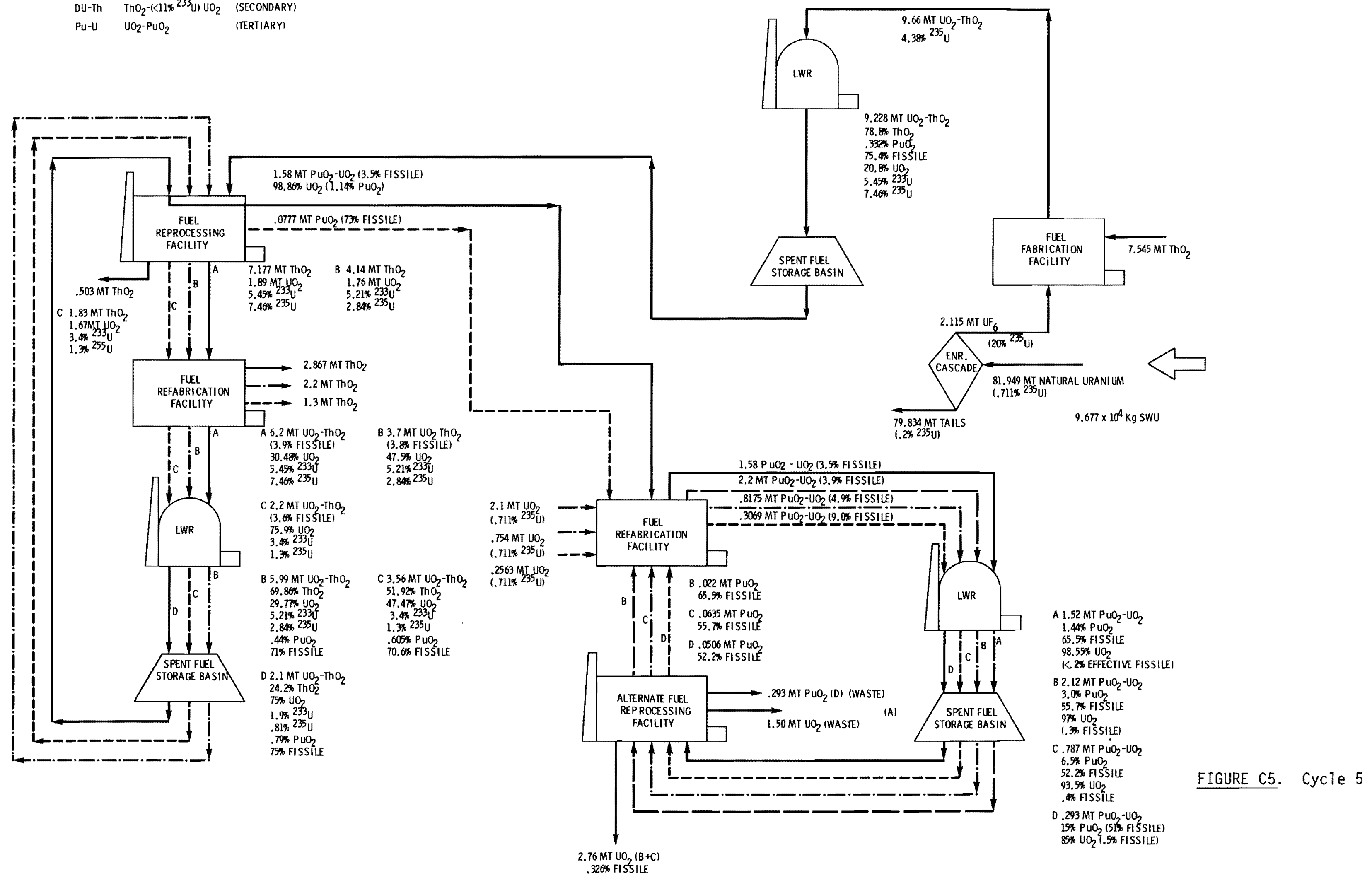
$9.42 \mathrm{MT} \mathrm{UO}_{2}-\mathrm{ThO}_{2}(4.38 \% 235 \mathrm{u})$
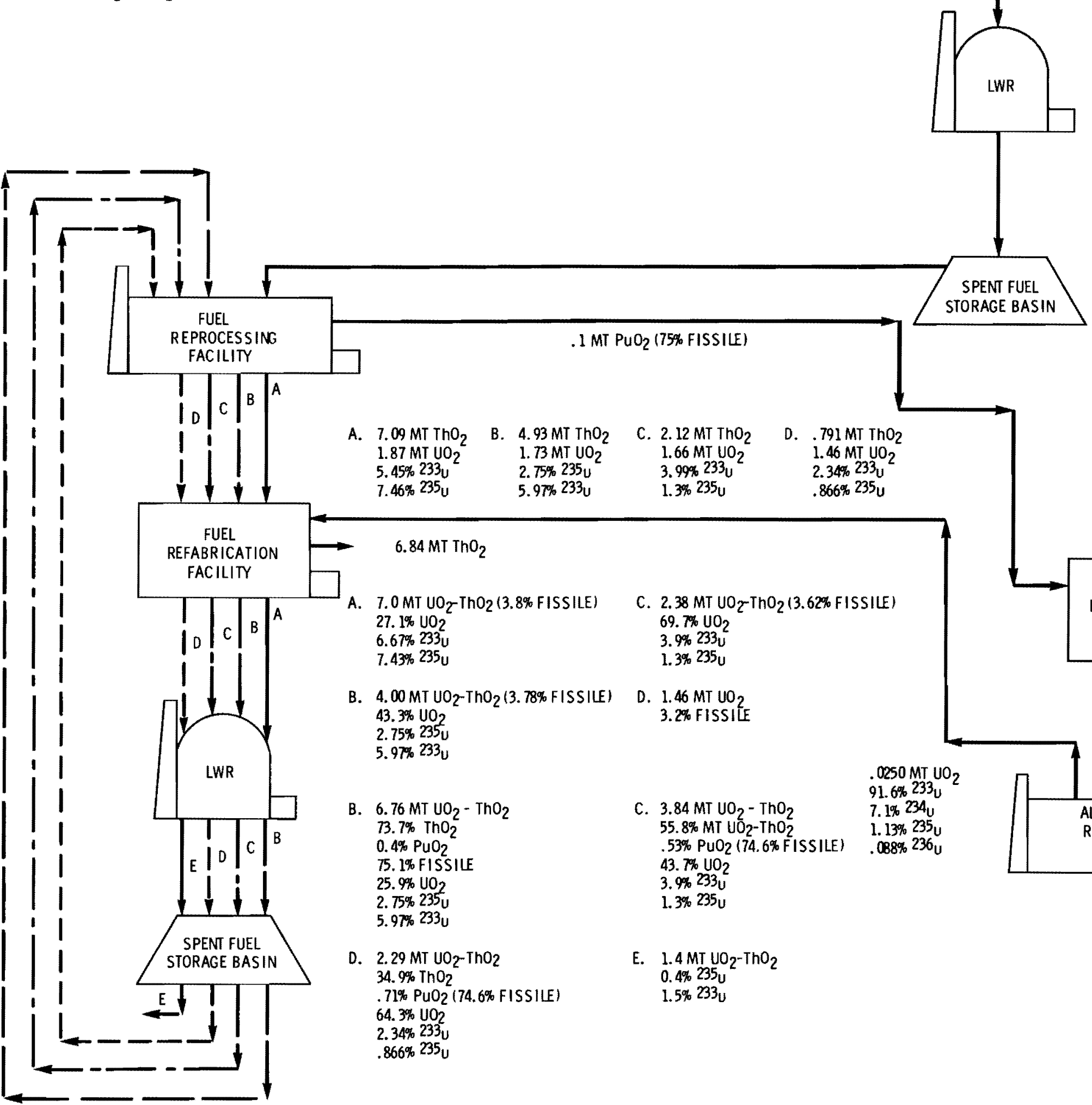

$\begin{array}{llll}\text { A. } & 7.09 \mathrm{MT} \mathrm{ThO}_{2} & \text { B. } 4.93 \mathrm{MT} \mathrm{ThO}_{2} & \text { C. } \\ 1.87 \mathrm{MT} \mathrm{UO}_{2} & \text { 1.73 MT U0 } & & \end{array}$ $5.45 \% 233 \mathrm{U}$ $.46 \% 235$ 2. $75 \% 253$

$6.84 \mathrm{MT} \mathrm{ThO}_{2}$

A. $7.0 \mathrm{MT} \mathrm{NO} \mathrm{O}_{2}-\mathrm{ThO}_{2}(3.8 \% \mathrm{FISSILE})$ $27.195 \mathrm{NO}_{2}$ $6.67 \% 233 \mathrm{u}$

B. $4.00 \mathrm{MT} \mathrm{UO}_{2}-\mathrm{ThO}_{2}$ (3.78\% FISS ILE) $43.3 \% \mathrm{UO}_{2}$
$2.75 \% 235 \mathrm{U}$
$5.97 \% 233 \mathrm{u}$

B. $\begin{aligned} & 6.76 \mathrm{MT} \mathrm{UO}_{2}-\mathrm{ThO}_{2} \\ & 73.7 \% \mathrm{ThO}_{2}\end{aligned}$ $73.7 \% \mathrm{ThO}_{2}$ 0.4\% ${ }_{75} \mathrm{PuO}_{2}$ $25.9 \% 002$ 2. $73 \% 235$ $5.97 \% 233 \mathrm{U}$

D. $2.29 \mathrm{MT} \mathrm{UO}_{2-\mathrm{ThO}}$ 34. $9 \% \mathrm{ThO}_{2}$
$.71 \% \mathrm{PuO}_{2}$ (74.6\% FISSIIE) $64.3 \% \mathrm{UO}_{2}$ $2.34 \% 23 \%$
$.866 \%$
$235 \%$

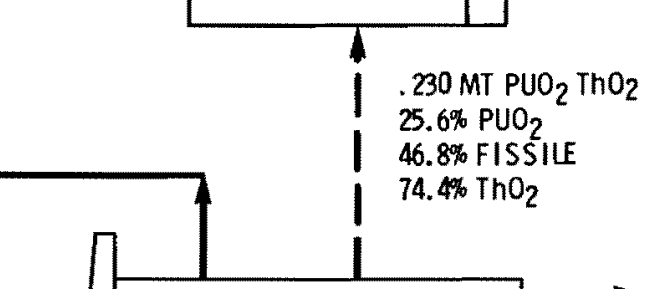

$9.1 \mathrm{MT} \mathrm{UO}_{2}-\mathrm{ThO}_{2}$

$78.8 \% \mathrm{ThO}_{2}$

$.73 \% 2 \% \mathrm{PuO}_{2}$
$.33 .4 \% \mathrm{FISSILE}$

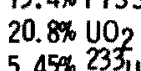

$5.45 \% 235$
$7.46 \%$
7350

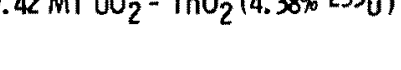
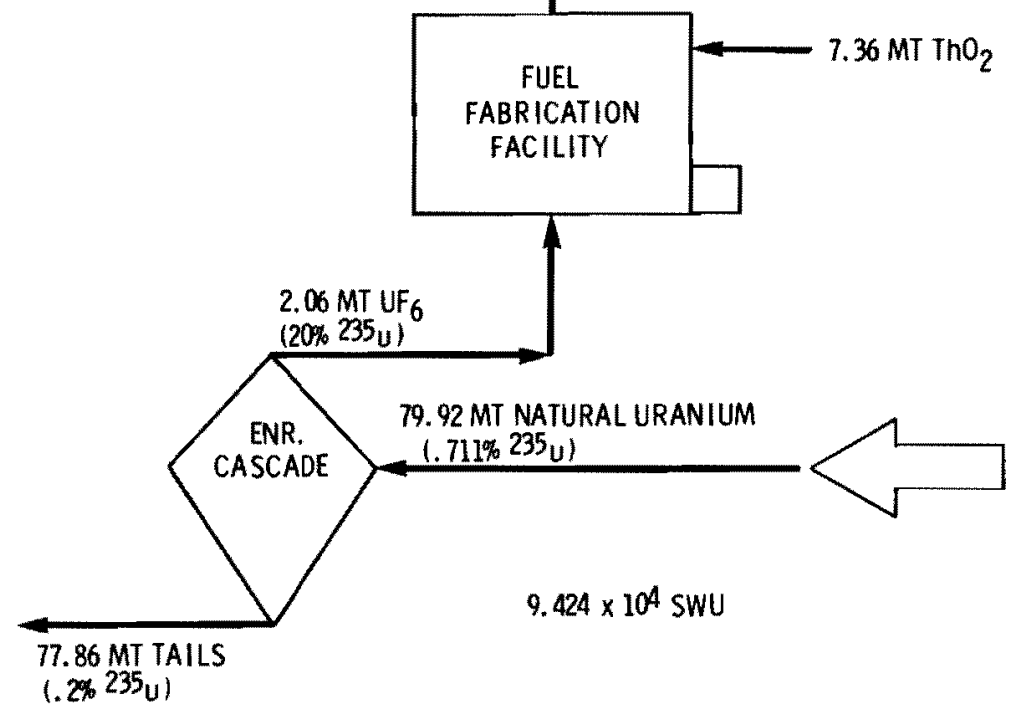

$\begin{array}{ll}2.12 \mathrm{MT} \mathrm{ThO}_{2} & \text { D. } \\ 1.66 \mathrm{MT} \mathrm{UO}_{2} & 791 \mathrm{MT} \mathrm{ThO} \\ \text { 1.46 MT UO } & \end{array}$ \begin{tabular}{ll}
$3.996233_{\mathrm{u}}$ & $1.46 \mathrm{MT}^{2} \mathrm{O}_{2}$ \\
$1.34 \%$ & $233 \mathrm{u}_{\mathrm{u}}$ \\
\hline
\end{tabular} SPENT FUEL
STORAGE BASIN

2.38 $\mathrm{MT} \mathrm{UO}_{2} \mathrm{ThO}_{2}$ (3.62\% FISSILE) 69. $7 \% \mathrm{UO}_{2}$ $3.9 \% 233 \mathrm{u}$
$1.3 \% 635 \mathrm{u}$

$1.3 \% 235 \mathrm{U}$

1. $46 \mathrm{MT} \mathrm{UO} 2$
3. $2 \% \mathrm{FISSIE}$

$3.84 \mathrm{MT} \mathrm{UO}_{2}-\mathrm{ThO}_{2}$
$55.8 \% \mathrm{MT} \mathrm{UO}_{2}-\mathrm{ThO}_{2}$

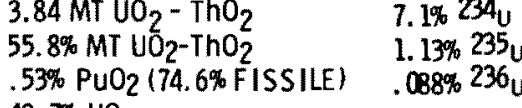

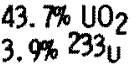
$3.9 \% 235 \mathrm{u}$
$1.3 \%$

E. $1.4 \mathrm{MT}_{0.4 \%} \mathrm{UO}_{2}-\mathrm{ThO}_{2}$ $0.4 \% 233_{\mathrm{u}}$
$\mathrm{N}$

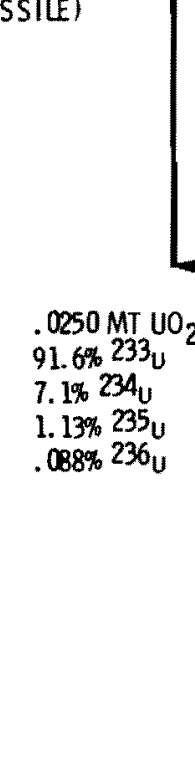
1.7 MT PuO2 $-\mathrm{ThO}_{2}(4.5 \%$ FISSIIF)

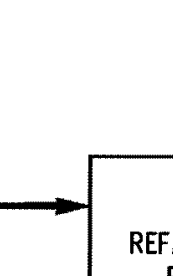

$1.6 \mathrm{MT} \mathrm{ThO}_{2}$

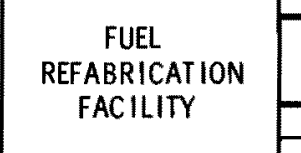

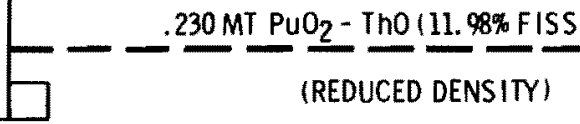

$230 \mathrm{MT} \mathrm{PUO}_{2} \mathrm{ThO}_{2}$

(REDUCED DENSITY)
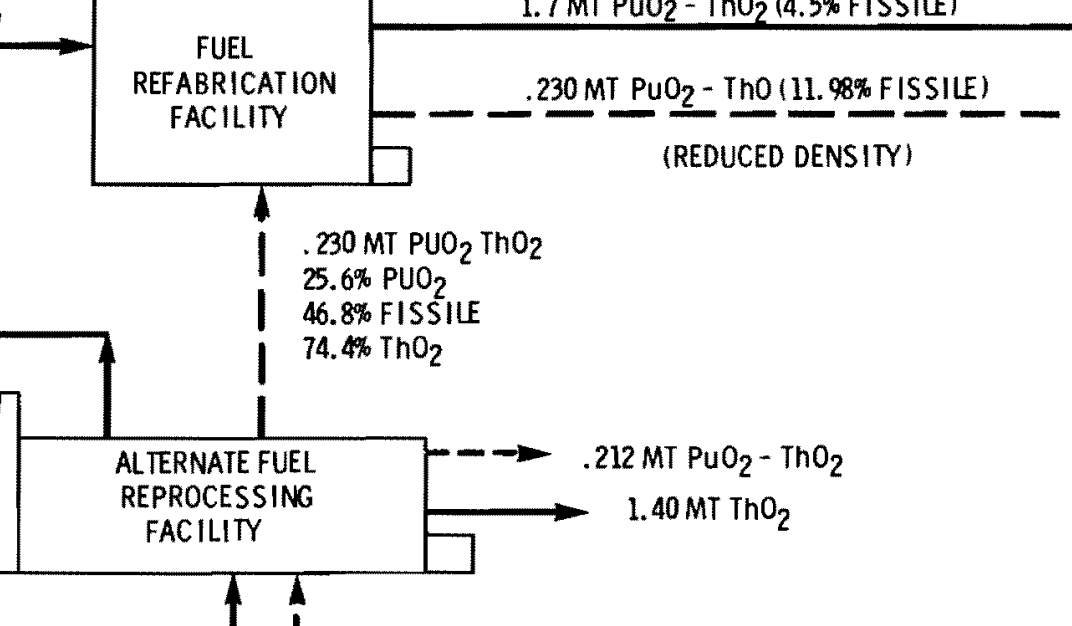

$\hat{\imath}$ 
FIGURE C-7:

CYCLE 7 - FUEL CYCLE CONSTITUENTS

HEU-Th ThO - 19356 235UNO2 (PRIMARY)

HEU-Th ThOZ-(233), ${ }^{235}{ }^{2}$ ) UO2 2 (SECONDARY)

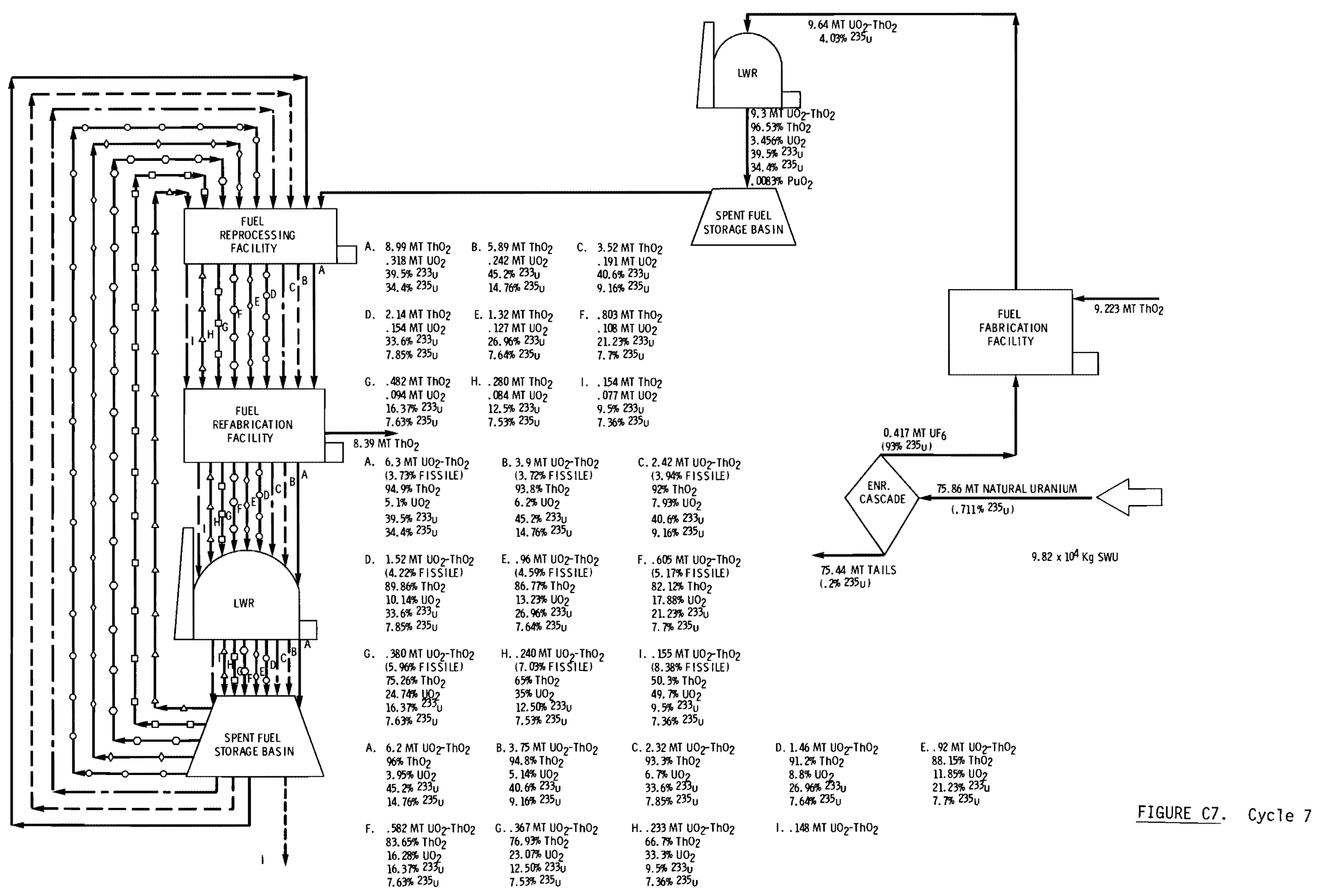




\section{DISTRIBUTION}

\section{OFFSITE}

No. of Copies

W.W. Ballard

U.S. Department of Energy-HQ

Washington, DC 20545

Orville Roth

U.S. Department of Energy-HQ

Washington, DC 20545

Jack Yanoski

U.S. Department of Energy

Nuclear Power Division

Washington, DC 20545

W.M. Shaffer

U.S. Department of Energy

Savannah River Operations Office

P.0. Box "A"

Aiken, SC 29801

Fred Dearing

U.S. Department of Energy

Oak Ridge Operations Office

P.0. Box "E"

Oak Ridge, TN 37830

Argonne National Laboratory (1)

9700 South Cass Avenue

Argonne, IL 60439

Babcock \& Wilcox (3)

P.0. Box 1260

Lynchburg, VA 24505

Bettis Atomic Power Laboratory (1)

Westinghouse Electric Corp.

P.0. Box 79

West Misslin, PA 15122

Combustion Engineering (1)

Nuclear Power Division

1000 Prospect Hill Rd.

Windsor, CT 06095

Electric Power Research Institute (1)

3412 Hillview Avenue

P.0. Box 10412

Palo Alto, CA 94304
No. of Copies

General Electric Company (3)

175 Curtner Avenue

San Jose, CA 95125

Los Alamos Scientific Laboratory (1) P.0. Box 1663

Los Alamos, NM 37545

Oak Ridge National Laboratory (4)

P.0. Box "X"

Oak Ridge, TN 37830

Sandia Laboratory (1)

Albuquerque, NM 87185

Savannah River Laboratory (3)

E.I. DuPont Denemurs \& Co.

Savannah Laboratory

Aiken, SC 29801

Westinghouse Electric Corp. (4)

P.0. Box 355

Pittsburgh, PA 15230

DOE Technical Information Center (27)

Department of Nuclear Engineering (1) Kansas State University

Manhattan, KS 66502

Department of Nuclear Engineering (1) University of Washington

Seattle, WA 98195

A.A. Churm

DOE Patent Division

9800 S. Cass Avenue

Argonne, IL 60439

ONS ITE

DOE Richland Operations Office

H. E. Ransom

61 Pacific Northwest Laboratory

W.J. Bailey

A.J. Boegel 
PNL -2779

UC -78

ONSITE (cont'd)

D.W. Brite

C.L. Brown

J.R. Carrell

N.E. Carter

T.D. Chikalla

E.D. Clayton

E.A. Eschbach

W.D. Felix

R.M. Fleischman

S. Goldsmith

P.E. Hart

R.S. Kemper

L.R. Lambert

R.C. Lijkala

T.I. McSweeney

J.F. Nesbitt

D.F. Newman

A.M. Nolan

A.M. Platt

D.L. Prezbindowski

R.E. Schrieber

R.E. Sharp

M.K. White

Publishing Coordination (2)

Technical Information (5)

FRAD Program Office Files (5)

Extra (20)

Richland Operations (2)

Hanford Engineering Development Laboratory (4)

Exxon Nuclear Company (2) 